\title{
Plant Occurring Flavonoids as Modulators of the Aryl Hydrocarbon Receptor
}

\author{
Elizabeth Goya-Jorge ${ }^{1,2}$ D, María Elisa Jorge Rodríguez ${ }^{3}$, Maité Sylla-Iyarreta Veitía ${ }^{4}$ and Rosa M. Giner ${ }^{1, *(D)}$ \\ 1 Departament de Farmacologia, Facultat de Farmàcia, Universitat de València. Av. Vicente Andrés Estellés, \\ s/n, Burjassot, 46100 Valencia, Spain; egojor@alumni.uv.es \\ 2 ProtoQSAR SL., CEEI (Centro Europeo de Empresas Innovadoras), Av. Benjamin Franklin 12, Parque \\ Tecnológico de Valencia, Paterna, 46980 Valencia, Spain \\ 3 Departamento de Farmacia, Facultad de Química-Farmacia, Universidad Central "Marta Abreu" de las Villas, \\ C. Camajuaní km 5ํㅡㄹ, Santa Clara 54830, Villa Clara, Cuba; elisa@uclv.edu.cu \\ 4 Equipe de Chimie Moléculaire du Laboratoire Génomique, Bioinformatique et Chimie Moléculaire (EA 7528), \\ Conservatoire National des Arts et Métiers (Cnam), 2 Rue Conté, HESAM Université, 75003 Paris, France; \\ maite.sylla@lecnam.net \\ * Correspondence: rosa.m.giner@uv.es; Tel.: +34-963-543-609
}

Citation: Goya-Jorge, E.; Jorge Rodríguez, M.E.; Veitía, M.S.-I.; Giner, R.M. Plant Occurring Flavonoids as Modulators of the Aryl Hydrocarbon Receptor. Molecules 2021, 26, 2315. https://doi.org/10.3390/ molecules 26082315

Academic Editors: Roberto Fabiani and Eliana Pereira

Received: 16 March 2021

Accepted: 13 April 2021

Published: 16 April 2021

Publisher's Note: MDPI stays neutral with regard to jurisdictional claims in published maps and institutional affiliations.

Copyright: (c) 2021 by the authors. Licensee MDPI, Basel, Switzerland. This article is an open access article distributed under the terms and conditions of the Creative Commons Attribution (CC BY) license (https:/ / creativecommons.org/licenses/by/ $4.0 /)$.

\begin{abstract}
The aryl hydrocarbon receptor (AhR) is a transcription factor deeply implicated in health and diseases. Historically identified as a sensor of xenobiotics and mainly toxic substances, AhR has recently become an emerging pharmacological target in cancer, immunology, inflammatory conditions, and aging. Multiple AhR ligands are recognized, with plant occurring flavonoids being the largest group of natural ligands of $\mathrm{AhR}$ in the human diet. The biological implications of the modulatory effects of flavonoids on AhR could be highlighted from a toxicological and environmental concern and for the possible pharmacological applicability. Overall, the possible AhR-mediated harmful and/or beneficial effects of flavonoids need to be further investigated, since in many cases they are contradictory. Similar to other AhR modulators, flavonoids commonly exhibit tissue, organ, and species-specific activities on AhR. Such cellular-context dependency could be probably beneficial in their pharmacotherapeutic use. Flavones, flavonols, flavanones, and isoflavones are the main subclasses of flavonoids reported as AhR modulators. Some of the structural features of these groups of flavonoids that could be influencing their AhR effects are herein summarized. However, limited generalizations, as well as few outright structure-activity relationships can be suggested on the AhR agonism and/or antagonism caused by flavonoids.
\end{abstract}

Keywords: flavonoids; phytochemicals; phytocompounds; Ah receptor; dioxin receptor; polyphenols; transcription factor; bioactive; xenobiotics; functional food

\section{Introduction}

Flavonoids are the largest class of phenolic compounds found in nature, particularly important in the plant kingdom. In multiple plants, flavonoids are responsible for the color and flavor [1]. The aglycone and glycoside (i.e., glucosides, rhamnoglucosides, and rutinosides) forms of flavonoids are found in the human daily diet like fruits, vegetables, grains, seeds, bark, herbs, roots, flowers, stems, and spices. The natural distribution of these plant secondary metabolites, their inherent structural diversity, chemical properties, and ability to interact with biological systems modifying multiple target receptors in mammalians, have attracted attention during decades to their study in pharmacological and toxicological contexts [2,3].

Among the wide range of biological properties referable to flavonoids are included antioxidant, anti-inflammatory, antitumor, antiviral, hypolipidemic, antithrombotic, estrogenic, and antiallergic activities. Moreover, numerous pre-clinical and epidemiological studies reveal that flavonoids may exert protective effects against chronic conditions such 
as cancer, diabetes, and cardiovascular and neurodegenerative diseases, supporting the concept of a beneficial role for dietary flavonoids in human health [4-7].

The cellular detection of chemical signals from exogenous or endogenous sources can occur through chemoreceptors that commonly have cytoplasmic or transmembrane locations. The cytosolic chemosensor AhR is an evolutionarily conserved protein and a pleiotropic transcription factor with a key role in both health and diseases [8,9]. The signaling pathways of the formerly known as "dioxin receptor" have explained the mode of action of highly toxic chemicals, particularly 2,3,7,8-tetrachlorodibenzo-p-dioxin (TCDD) and derivatives [10]. Recently, there is increasing attention on AhR as an attractive target in cancer, immunology, inflammatory bowel diseases, and aging [11]. However, much about the molecular mechanisms and the activation/inactivation patterns of AhR upon ligand binding is pending closer analyses [12].

Multiple and structurally diverse chemicals including polyhydroxyalkanoates, polychlorinated biphenyls, bisphenols, polyphenols, benzothiazoles, and triarylmethanes have been evaluated as AhR ligands [13-15]. Plant flavonoids are considered the main group of natural dietary ligands of the AhR $[16,17]$. Hence, several well-known activators and inhibitors of AhR-mediated effects are flavonoids, with the flavonol quercetin being a prototypical representative. Depending on the cell context, quercetin has shown agonist and/or antagonist activities on AhR transcriptional activation [18]. This could suggest selective AhR modulation in which agonism or antagonism must be confirmed, as it is not clearly predictable [19].

This literature review provides a summary and update of the most recent state of the art on $\mathrm{AhR}$ and its natural flavonoid modulators. First, a detailed introduction is given on AhR's molecular characteristics and signaling pathways, including the main physiological effects associated with its transcriptional activity. Next, plant occurring flavonoids that have been evaluated as AhR modulators, and their AhR agonism and/or antagonism, are presented. Finally, some chemical-structural features and substitution patterns of flavonoids that could be contributing to their AhR activity, are suggested.

\section{Aryl Hydrocarbon Receptor}

\subsection{Functional Domains}

The transcription factor AhR was originally discovered in hepatocytes in the 1970s. Half a century later, multiple studies have confirmed that AhR signaling affects virtually every animal cell-type and organ in vertebrates and in many invertebrates [8]. The highest AhR expression has been reported in the liver, kidney, thymus, lung, spleen, and placenta [20]. Moreover, AhR is constitutively allocated in the nucleus of aggressive malignancies, where its target genes are widely expressed [21]. Figure 1 is a schematic representation of the AhR functional domains and binding sites.

The AhR and its nuclear translocator (ARNT) belong to the bHLH-PAS superfamily of transcription factors, the acronym for basic Helix-Loop-Helix and Periodic (PER)-ARNTSingle minded (SIM) [22]. Protein subfamilies may be stratified into two classes, with Class I including bHLH-PAS proteins such as the AhR, hypoxia-inducible factors, clock circadian regulators, and neuronal PAS protein, while Class II includes the ARNT subfamily of proteins located inside the nucleus and can heterodimerize with the cytosolic Class I members such as AhR. Both AhR and ARNT include an (N-) terminal bHLH domain, two PAS domains named A and B, and a transactivation domain carboxy (C-) terminal $[23,24]$. The PAS A domain controls dimerization through its connector helix and strengthens the binding to a distinct DNA motif in which bHLH plays the main role. With a three-loop insertion difference from PAS A, the PAS B is the AhR ligand-binding domain (LBD) [25]. In the transactivation domain, the Q-rich (Glutamine-rich) subdomain is the key region for transcriptional activation of xenobiotic response elements (XRE) in the DNA [26]. The binding to coactivators during the transcriptional process regulates the wide diversity and tissue specific AhR effects [27]. 


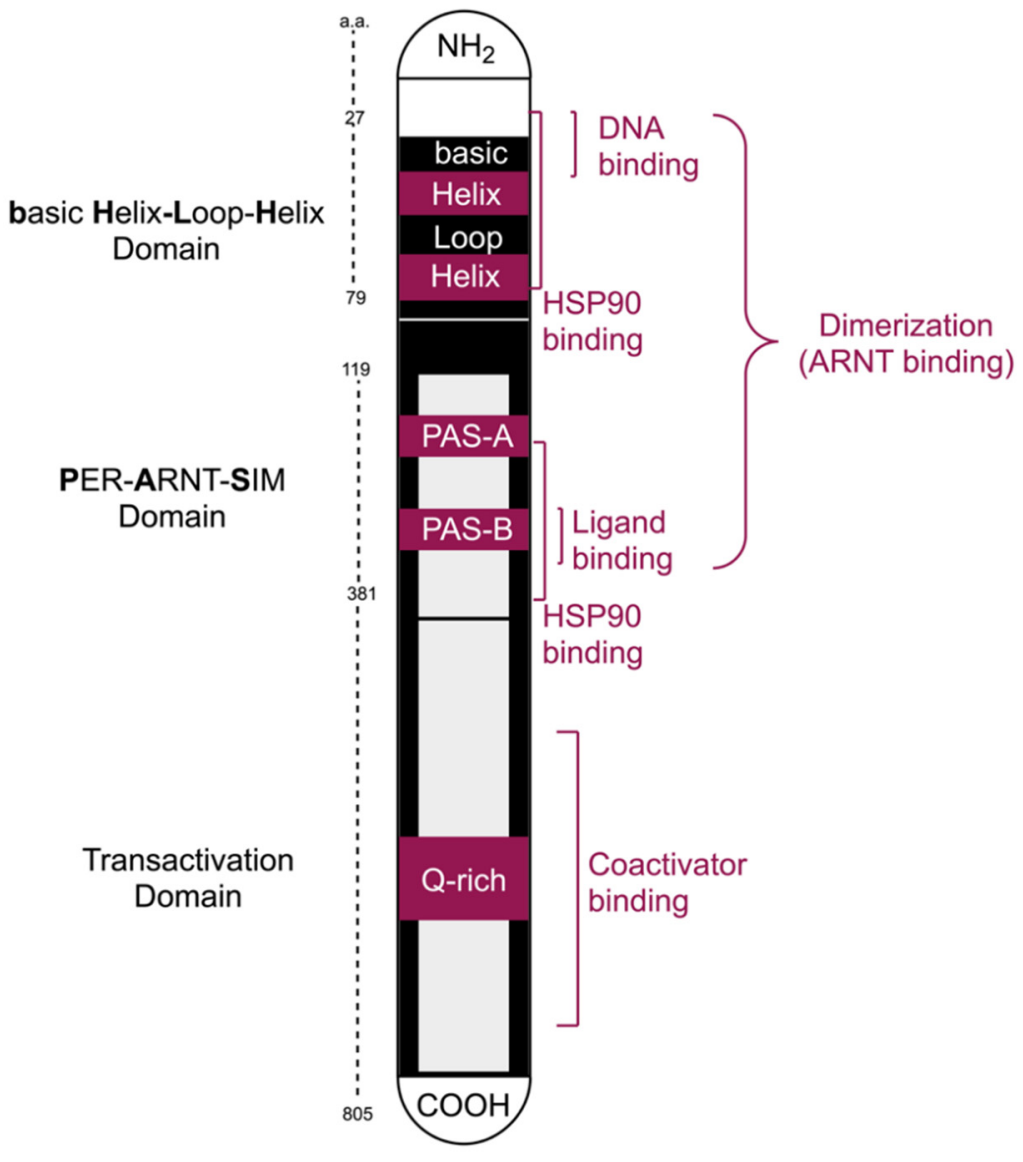

Figure 1. Schematic domain organization of the aryl hydrocarbon receptor (AhR) and its binding sites.

\subsection{Cytoplasmic Complex and Signaling Pathways}

The cytoplasmic inactive form of AhR (monomer) is found to be associated with two molecules of the 90-kDa heat shock protein (HSP90) chaperone, a co-chaperone $\mathrm{p} 23$, a termed X-associated protein 2 (XAP2), and a protein kinase SRC. While one of the HSP90 interacts with both the bHLH and PAS regions, the other unit is only bound to the PAS domain [28]. The HSP90 is a protein folding tool found also in steroid receptors such as estrogen, progesterone, and glucocorticoid receptors. The resistance to salt treatment and the absence of molybdate led to suggestions that HSP90/AhR binding may be the most stable binding known for that chaperone. However, inter-species differences for HSP90/AhR binding have been identified [29,30]. The co-chaperone p23 is a commonly found protein in HSP90 complexes, where it contributes to the ligand binding and to the release from HSP90 chaperone machinery [31,32]. More recently, a protecting role of p23 against AhR's degradation independent of HSP90's functions has been acknowledged [33]. Meanwhile, XAP2 presents a discrete domain organization with a tetratricopeptide repeat motif whose carboxyl-terminal domain is responsible for the interaction with AhR protein. In the AhR core complex, XAP2 positively or negatively modulates the receptor's sensitivity to ligands and the transcriptional responses [34-36]. The c-SRC tyrosine kinase contributes to ligand recognition and indirectly ensures the transcriptional process [37]. Figure 2 represents some of the molecular consequences upon ligand binding to the AhR complex. 

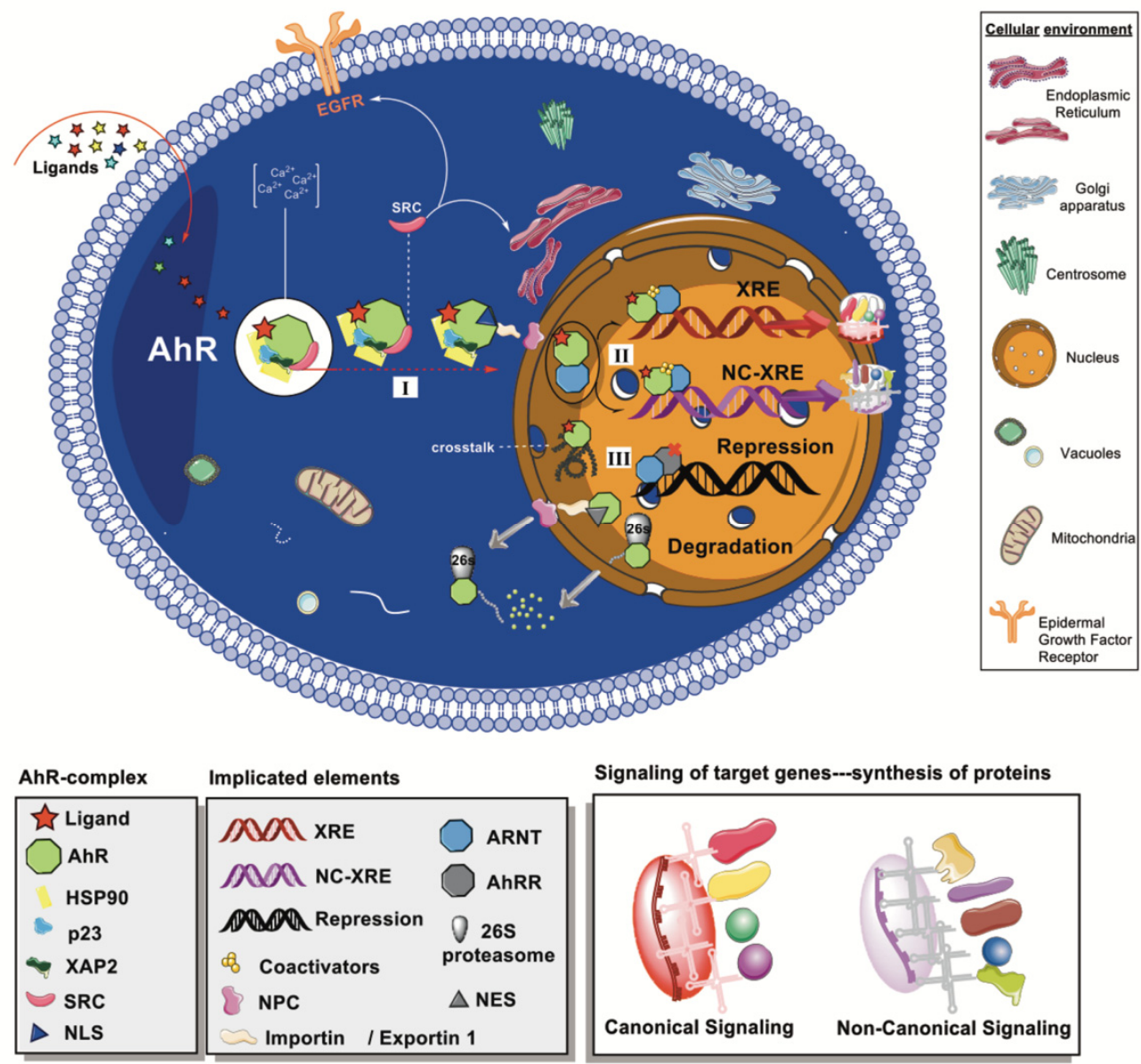

Figure 2. Schematic representation of AhR-mediated pathways. Ligands bind to the cytoplasmic AhR, where it forms a complex with HSP90, p23, XAP2, and SRC. (I) Agonist ligands promote conformational changes and the exposure of NLS, allowing the nuclear translocation mediated by importin $\beta$ through the NPC. (II) Once in the nucleus, the heterodimer AhR-ARNT can bind to different sequences in the DNA and trigger the synthesis of proteins (e.g., CYP1A1, UGT1A6), which is additionally regulated by coactivators. (III) Crosstalk interactions with other signaling pathways are acknowledged (e.g., ESRs, AR). Moreover, the Ah receptor can be repressed by AhRR, and its degradation is mainly mediated by $26 \mathrm{~S}$ proteasome.

Genomic and non-genomic pathways are suggested for AhR signaling, as represented in Figure 2. The genomic induction of target genes is the fundamental and best-known mechanism of AhR-mediated signaling. The genomic pathway (I) starts once AhR agonists bind to the LBD, causing conformational changes in the PAS A that trigger the exposure of nuclear localization sequences (NLS) [38,39]. The SRC is then released from the AhRchaperone complex to the cytosol, triggering phosphorylation processes [40]. The entrance to the nucleus is facilitated by importins that recognize the NLS. Specifically, importin $\beta$ is the direct mediator that facilitates the passage to the cytoplasmic face of the nuclear pore complex (NPC) [41].

After the AhR-chaperone complex is translocated to the nucleus, the receptor heterodimerizes with ARNT, losing the chaperone proteins in the process and forming the AhR/ARNT complex (II in Figure 2) [42]. Depending on the target genes involved in the subsequent transcriptional activity triggered by the AhR/ARNT, the genomic signaling is classified as canonical when it is mediated by XRE or else as non-canonical or no consensus XRE (NC-XRE) responses (Figure 2). The canonical signaling starts when the AhR/ARNT complex binds to the XRE identified by the DNA consensus motif sequence $5^{\prime}$ TNGCGTG-3' $[43,44]$. The NC-XREs, sometimes referred to as AhR Responsive Elements-II, 
are recognized by the consensus promoter region $5^{\prime}$-CATG $\{\mathrm{N} 6\} \mathrm{C}[\mathrm{T}$ | A]TG-3' [45]. A scaffold is formed upon binding to AhR core regions, inducing the recruitment of multiple coactivators that ultimately regulate the transcriptional process [27]. In addition, similar to other PAS proteins involved in critical signaling functions, AhR expression is controlled by a transcriptional repressor (AhRR) with a similar N-terminal region sequence [46]. Thus, the AhRR is an AhR competitor in that it may form the heterodimeric AhRR/ARNT complex, which binds to the XRE, and consequently repress the transcription. The AhRR effects mediate key processes such as inflammation and tumor growth that have led to its consideration as a drug target $[47,48]$. The repression pathway is also controlled by the receptor itself and its transcriptional outcomes forming a regulatory circuit [49].

The prototypical canonical target gene identified for AhR determines the induction of cytochrome P450 from family 1, subfamily A, polypeptide 1 (CYP1A1) xenobioticmetabolizing enzyme $[50,51]$. At the same time, AhR regulates the basal CYP1A1 expression through elements such as the so-called special protein family, and particularly the specificity protein 1 [52]. Moreover, AhR signaling through XRE has been associated with other family members such as CYP1A2 and CYP1B1 as well as phase II enzymes such as the UGT1A6 [53,54]. The understanding of the AhR complexity has been further expanded with the discovery of multiple nonclassical target genes in the past decades [55]. Some of the most important NC-XRE pathways are related to the tumor suppressor Kruppel-like factor 6 and the recruitment of flanking target genes such as the plasminogen activator inhibitor 1 and the $\mathrm{p}^{2} 1^{\mathrm{cip} 1}$ protein [56].

Among the non-genomic mechanisms that $\mathrm{AhR}$ activation could trigger is the abovecommented phosphorylation induced by the c-SRC of multiple key protein substrates such as the epidermal growth factor receptor (EGFR) $[57,58]$. Furthermore, c-SRC, the mitogenactivated protein kinases, reactive oxygen species (ROS), and AhR-dependent paths have been recently associated with the apoptosis of neuronal cells through the stress of the endoplasmic reticulum [59]. The proteasome-mediated degradation of ubiquitinated proteins is another important non-genomic pathway of AhR activation, which has been linked to the inflammatory process $[60,61]$. Thus, AhR can act as a ligand-dependent ubiquitin protein ligase (E3), promoting the proteolysis of other transcription factors [62,63]. Furthermore, AhR controls the levels of intracellular calcium and the induction of enzymes such as the cytosolic phospholipase A2 and cyclooxygenase $2[64,65]$.

On the other hand, AhR modulation intervenes in the signaling networks of many other crucial cellular entities [66]. The crossroad with estrogen receptors (ESR $\alpha$ and ESR $\beta$ ) is among the best-studied and it has been shown to lead to transcriptional activation of estrogen-responsive gene promoters and the consequent estrogenic effects [67]. Besides, $\mathrm{AhR}$ has proven to interact with the canonical Wnt/ $\beta$-catenin pathway possibly mediated by some other entities such as R-spondin 1 [68], which is an important element in cellular proliferation as well as in sexual organ's development and differentiation [69,70]. Such an interaction associates the receptor with the regulation of organogenesis and other key biological processes such as cell polarity and migration attributed to the glycoproteins Wnts [71].

AhR crosstalk interactions include effects on the transforming growth factor- $\beta$ /bone morphogenetic protein (TGF $\beta / \mathrm{BMP}$ ) pathway. TGF $\beta$ / BMP is a target of drugs currently in phase I or phase II clinical trials for the treatment of ovarian cancer, hepatocellular carcinoma, glioblastoma, and melanoma [72]. In addition, the subunit RelB of NF-kB transcription factor family has shown to be functionally associated with AhR-mediated transcription. The resulting RelB/AhR complexes play an important role as inducers of pro-inflammatory chemokines such as IL-8, and this crosstalk mechanism is critically involved in immunity, cell proliferation, and apoptosis [73,74].

Lastly, the downregulation of AhR is described as a rapid crucial attenuation of AhR effects on gene transcription. The proteolytic degradation is a terminal step mainly ubiquitin-mediated through the $26 \mathrm{~S}$ proteasome. It could be triggered if the receptor complex has a misfolded conformation prior to entry to the nucleus. Otherwise, after the 
signaling processes, AhR is ubiquitinated and degraded inside the nucleus or transferred to the cytoplasm via the Exportin 1 (or CRM-1) that recognizes the nuclear export signals (NES). In the cytosol, AhR is targeted and degraded by $26 \mathrm{~S}$ proteasome [75,76]. Recently, lysosomal degradation of AhR via chaperone-mediated autophagy has been identified in triple-negative breast cancer cells [77].

\subsection{AhR Effects and Modulators}

The ligand, cell, tissue-specific, and pleiotropic effects of AhR-mediated activity are still puzzling and, in many cases, poorly understood [78]. Human diet and gut microbiome are tremendous sources of AhR modulators that trigger complex and fundamental processes in health and diseases [79,80]. It is believed that at least the downstream effects of dietary AhR inducers fit the renowned quote of the father of toxicology Paracelsus that "Sola dosis facit venenum" (the dose makes the poison) [12]. However, the receptor's occupancy and the persistence of modulators are suggested to be, in many cases, far more relevant than the dosage. Low dosage effects still are underestimated and not fully understood by current science. Overall, AhR pathways intricacies have led some to consider that many of its adverse health consequences could be an exacerbated cellular response to its endogenous roles $[66,81]$. The truth is that these contradictory statements remain to be clarified on this fascinating transcription factor [10].

Toxicologists have been for decades interested in AhR-dependent signaling as a key intermediate step in the toxic responses to dioxin-like compounds [10]. Immunological, hepatic, and endocrine disruptions, as well as carcinogenic effects, are attributed to AhRmediated activity [55]. However, the proven AhR physiological functions, particularly important in barrier organs as the gut or the skin, are nowadays driving a new line of research for the formerly known as "dioxin receptor" [9].

AhR has been associated with key processes such as development, cell cycle regulation, immunity, resilience against stress, homeostasis, and metabolism [82]. Potential therapeutic uses of AhR modulation include maintenance of lung health [83], control of the inflammatory process in vascular tissues [84], treatment of liver and cystic fibrosis [85,86], control of the antioxidant response [87], and regulation of neural functions in both vertebrates and invertebrates [88].

Numerous and structurally diverse chemical entities have been identified as AhR agonist and/or antagonist modulators (Figure 3). Hence, the receptor has been considered a "promiscuous" sensor of chemical entities [89]. Endogenous entities such as the tryptophan derivative 6-formylindolo [3, 2-b]carbazole (FICZ) [90] and the neurotransmitter serotonin [91], are AhR modulators. Exogenous compounds exhibiting AhR modulatory effects include the toxicant TCDD, the synthetic alpha-Naphthoflavone and the drug Phorthress, as well as naturally occurring compounds such as berberine, quercetin, and resveratrol.

Discovering chemical entities acting as AhR agonists and antagonists contribute to a better understanding of the molecular interactions as well as the toxicological and therapeutic roles of the receptor [92]. In toxicology, this has helped to identify potential high concern substances and environmental contaminants, particularly persistent organic pollutants whose exacerbated effects could trigger the adverse outcomes associated with AhR transcriptional activity [93].

Inflammatory and immunological diseases could be modulated through AhR expression and particularly those affecting gut and intestinal tissues $[79,80,94]$. Thus, promising drug candidates such as the designed AhR ligands NPD-0414-2 and NPD-0414-24, have been recently suggested in the therapy of colitis [95]. However, probably the most significant pharmacological applications of targeting AhR are in the treatment of malignancies. Hence, the chemotherapy of CYP1A1-positive tumors includes AhR agonists such as Phortress (NSC 710305) [96] and Aminoflavone (NSC 686288) [97], with demonstrated antiproliferative activity through AhR activation. 


\section{AHR ENDOGENOUS MODULATORS}

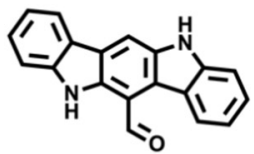

FICZ

172922-91-7<smiles>CC12CCc3c(ccc4cc(O)ccc34)C1CCC2=O</smiles>

Equilenin 517-09-9<smiles>Nc1ccccc1C(=O)CC(N)C(=O)O</smiles>

Kynurenine

343-65-7<smiles>NCCc1c[nH]c2ccc(O)cc12</smiles>

Serotonin 50-67-9<smiles>CCCCC(O)/C=C/C=C/C=C/C=C/C(O)C(O)CCC(=O)O</smiles>

Lipoxin A4

89663-86-5

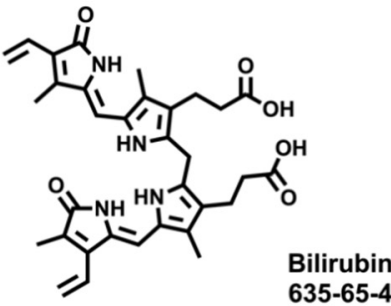

\section{AHR EXOGENOUS MODULATORS}

Synthetic<smiles>Clc1cc2c(cc1Cl)Oc1cc(Cl)c(Cl)cc1O2</smiles><smiles>O=c1cc(-c2ccccc2)oc2c1ccc1ccccc12</smiles><smiles>Cc1cc(-c2nc3cc(F)ccc3s2)ccc1NC(=O)C(N)CCCCN</smiles>

TCDD 1746-01-6 alpha-Naphthoflavone 604-59-1 Phortress
741241-36-1

Natural

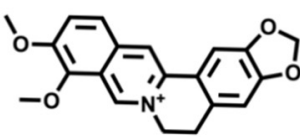

Berberine 2086-83-1<smiles></smiles>

Quercetin 117-39-5<smiles>Oc1ccc(/C=C/c2cc(O)cc(O)c2)cc1</smiles>

Resveratrol 501-36-0

Figure 3. Examples of AhR endogenous and exogenous modulators (structures, common names, and CAS numbers are shown).

Some authors suggest the term of selective AhR modulators (SAhRMs) instead of common categorizations based on their binding affinity, structural similarities, origins, or toxicity. Such a consideration is based on the tissue, organ, and species-specific activities exhibited by most AhR ligands, but particularly by non-dioxin-like ligands such as flavonoids. Deeper investigations that focus on the selectivity patterns and the agonist and antagonist responses of AhR modulators could significantly contribute to their clinical applications and to the control of their toxicity [19].

\section{Flavonoids: Generalities and Modulating Effects of AhR}

Flavonoids are secondary metabolites widely distributed throughout the plant kingdom in both edible and non-edible species. Countless literature reports indicate a link between flavonoid's consumption and health benefits (or risks), due to their antioxidant, antiproliferative, estrogenic, or anti-estrogenic properties [98,99]. As a large reservoir of chemical diversity, plant polyphenols are involved in a varied spectrum of gene and enzymatic regulation mechanisms [100-102]. 
Structurally, flavonoids are characterized by their basic skeleton arranged in the form C6-C3-C6, which corresponds to two benzene rings linked by a unit of three carbon atoms, which may or may not give rise to a third ring. Despite the various criteria regarding their classification, three general classes are recognized according to the linkage position of the aromatic ring with respect to the benzopyrane (chromane) moiety: flavonoids (2phenyl-1,4-benzopyrones), isoflavonoids (3-phenyl-1,4-benzopyrones), and neoflavonoids (4-phenyl-1,2-benzopyrones) [101]. Moreover, they can be subclassified into subgroups according to the degree of oxidation of the pyranic ring, which can be opened and recycled in the furan cycle and linking chain unsaturation: 2-phenylchromones (flavones, flavonols, flavanones, and dihydroflavonols); 2-phenylchromanes (flavans, flavan-3-ols, flavan-3,4diols), chalcones (represented in Figure 4), and some others such as anthocyanins (2-phenylbenzopyrilium) and aurones $[2,3,103,104]$.
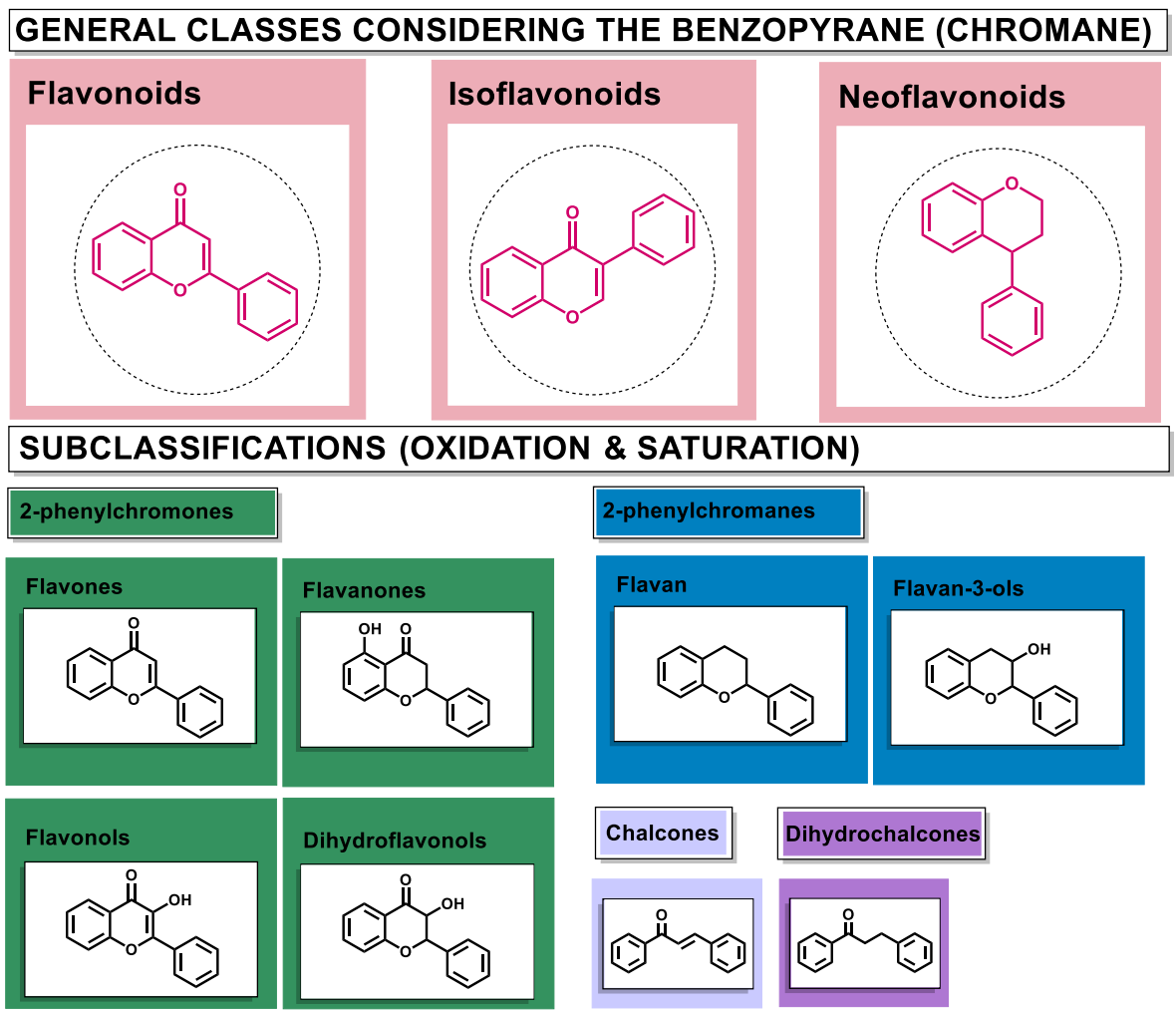

Figure 4. General classes of flavonoids and some relevant subclassifications.

Regarding their chemical reactivity, flavonoids occur as hydroxylated, methylated, and prenylated aglycones or glycosylated derivatives, either $O$-glycosides formed via linkage of the sugar unit to the hydroxyls, or C-glycosides directly to the carbon atom of the flavonoid skeleton [2,105]. In the cytosol ( $\mathrm{pH} 7.4)$, most flavonoids form a mixture of phenolate anions and neutral phenols. Their proportion depends on the $\mathrm{pK}$ a of each phenolic group in the structure. Since most flavonoids are weak hydrophobic acids, depending on their lipophilicity, they have the potential to cross cellular and mitochondrial membranes and act as protonophores. Sometimes even minimal structural modifications alter the solubility, reactivity, and stability of flavonoids that ultimately lead to their bioavailability differences and the diversity of biological effects across the groups [106,107].

The current uses of plant flavonoids cover cosmetic, nutraceutical, and pharmaceutical industries $[3,108,109]$. Their prophylactic efficacy against neoplastic [110-112], cardiovascular [113-115], bone [116], and neurological disorders [117] are among the most widespread. Pharmacological studies have revealed also anti-inflammatory $[118,119]$ and antibacterial potential [102] of flavonoids, as well as their applications in the prevention and treatment of obesity [120] and diabetes [121,122]. Besides, antioxidant effects have been attributed 
to all flavonoid subclasses [7]. Thus, most of the anticancer properties ascribed to plants and natural extracts from traditional medicine are explained through flavonoids' ability to scavenge free radicals and other ROS, modulate ROS-scavenging enzymes, chelate metal ions, and prevent oxidative stress-related conditions [104,123]. However, the mechanisms mediating the diverse bioactivity profiles of flavonoids, which are determined by minimal structural differences, still are pending further investigations [2,6].

A wide variety of flavonoids are suggested to be modulators of AhR function. The complexity of the role of AhR in physiology and in pathological conditions, lead to discrepancies in the positive or negative molecular consequences of the AhR transcriptional modulation caused by flavonoids $[11,16,124]$. Furthermore, it is recognized that beyond a dose dependence of food flavonoids when acting on AhR, these ligands could display different activities depending on the exposure time, and their effects are variable among species and tissues [125-127]. Table 1 shows the list of flavonoids studied as AhR modulators, the main bioassays used, and the common range of concentrations tested.

Table 1. Plant occurring flavonoids studied as aryl hydrocarbon receptor (AhR) modulators through different bioassays.

\begin{tabular}{|c|c|c|c|c|}
\hline Flavonoids & Bioassays $^{a}$ & Cell lines \& Tissues ${ }^{b}$ & {$[\mu \mathrm{M}]$} & Reference \\
\hline $\begin{array}{l}\text { Flavones } \\
\text { Acacetin, Apigenin, Baicalin, Chrysin, } \\
\text { Flavone, Genkwanin, Luteolin, } \\
\text { Luteolin 7,3'-diglucoside, Scutellarein, } \\
\text { Tangeretin, Tricetin, } \\
4^{\prime}, 7 \text {-dimethoxy-5-hydroxyflavone, } \\
4^{\prime}, 5,7 \text {-trimethoxyflavone, } \\
3^{\prime}, 4^{\prime}, 5,7 \text {-tetramethoxyflavone. }\end{array}$ & $\begin{array}{c}\text { RT-qPCR, PCR, } \\
\text { LucRGA, } \\
\text { ChIP, WB, } \\
\text { IF, IHC }\end{array}$ & $\begin{array}{c}\text { Caco2, YAMC, } \\
\text { DLN, HepG2 AhR-Lucia, } \\
\text { H1L6.1c2, 3T3-L1 (AhR) } \\
\text { HCT116, MDA-MB-231, } \\
\text { Hepatic tissue (rats), } \\
\text { Myocardial tissue (mice) }\end{array}$ & $10-100$ & [128-137] \\
\hline
\end{tabular}

\section{Flavonols}

Fisetin, Flavonol, Galangin, Gossypetin,

Guaijaverin, Icaritin, Isorhamnetin,

Kaempferol, Morin, Myricetin, Quercetin, RT-qPCR,

ChIP, WB,

Rutin. Tamarixetin,

Caco2, H1L6.1c2,

Caco2, H1L6.1c2,
3T3-L1 (AhR),
PBMEC $100-100,129,135$,

$3,6,2^{\prime}, 3^{\prime}$-Tetrahydroxyflavone,

$3,6,2^{\prime}, 4^{\prime}$-Tetrahydroxyflavone.

\begin{tabular}{lcccc}
\hline $\begin{array}{l}\text { Dihydroflavonols } \\
\text { Taxifolin, Dihydromyricetin }\end{array}$ & $\begin{array}{c}\text { RT-qPCR, ChIP, WB, } \\
\text { LucRGA }\end{array}$ & Caco2, HepG2 & $0.1-100$ & [135,140] \\
\hline $\begin{array}{l}\text { Flavolignane } \\
\text { Silymarin }\end{array}$ & LucRGA & H1L6.1c2 & 25 & {$[139]$} \\
\hline
\end{tabular}

\section{Flavanones}

Alpinetin, Eriodictyol, Flavanone,

Hesperetin, Hesperidin, Isoxanthohumol,

Naringenin, Naringin,

Naringenin Trimethyl Ether,

Sakuranetin, 6-Prenylnaringenin,

LucRGA

PBMEC/C1-2,

HepG2 AhR-Lucia

8-Prenylnaringenin

\begin{tabular}{|c|c|c|c|c|}
\hline $\begin{array}{l}\text { Flavan 3-ol } \\
\text { Epigallocatechin gallate }\end{array}$ & WB, LucRGA & $\begin{array}{c}\text { 3T3-L1 (AhR), } \\
\text { HepG2 AhR-Lucia }\end{array}$ & $30-100$ & {$[128,136]$} \\
\hline $\begin{array}{l}\text { Chalcone } \\
\text { Cardamonin }\end{array}$ & qPCR, WB & THP-1 & $3.0-30$ & [143] \\
\hline $\begin{array}{l}\text { Isoflavones } \\
\text { Biochanin A, Daidzein, Formononetin, } \\
\text { Genistein, Puerarin, Prunetin, } \\
4^{\prime}, 7 \text {-dimethoxy-5-hydroxyisoflavone, } \\
4^{\prime}, 5,7 \text {-trimethoxyisoflavone, } \\
3^{\prime}, 4^{\prime}, 5,7 \text {-tetramethoxyisoflavone }\end{array}$ & $\begin{array}{c}\text { RT-qPCR, LucRGA, } \\
\text { WB }\end{array}$ & $\begin{array}{c}\text { Caco2, YAMC, } \\
\text { H1L6.1c2, MCF-7, } \\
\text { HC-04, HepG2 (AZ-AhR), } \\
\text { Hepa-1c1c7, } \\
\text { HepG2 AhR-Lucia }\end{array}$ & $0.1-1000$ & $\begin{array}{l}{[136,137,139,} \\
144-146]\end{array}$ \\
\hline
\end{tabular}

${ }^{a}$ Bioassays: Chromatin immunoprecipitation (ChIP), Co-immunoprecipitation (Co-IP), EROD, ethoxyresorufin-O-deethylase (EROD), Immunofluorescence (IF), Immunohistochemical (IHC), Luciferase reporter gene assay (LucRGA), reverse transcriptase-quantitative polymerase chain reaction (RT-qPCR), western blotting (WB). ${ }^{b}$ Cell Lines: draining lymph node (DLN), human breast adenocarcinoma (MCF-7), human colon cancer (HCT116), human epithelial colorectal adenocarcinoma (Caco2), human hepatocyte (HC-04), human hepatoma (HepG2), human monocytic leukemia (THP-1), human prostate carcinoma (LNCaP, CWR22Rv1), mouse adipocytes (3T3-L1), mouse colonic epithelium (YAMC), mouse hepatoma (H1L6.1c2, Hepa-1c1c7), mouse lymphoblast (EL-4), porcine brain microvascular endothelium (PBMEC/C1-2). 
As presented in Table 1, in recent years, accurate and informative techniques such as RT-qPCR, LucRGA, ChIP, Co-IP, EROD, IF, IHC, and WB have been used to assess the modulatory capacity of flavonoids on AhR. Meanwhile, the tested concentrations are commonly between $10 \mu \mathrm{M}$ and $100 \mu \mathrm{M}$. The main subclasses of flavonoids studied as AhR modulators are flavones, flavonols, flavanones, and isoflavones. In these four classes, agonist and/or antagonist activities, as well as inactivity on AhR-mediated effects are reported, as summarized in Table 2 (Flavones), Table 3 (Flavonols), Table 4 (Flavanones), and Table 5 (Isoflavones).

Table 2. Structures and AhR activity reported for the flavone class of compounds.

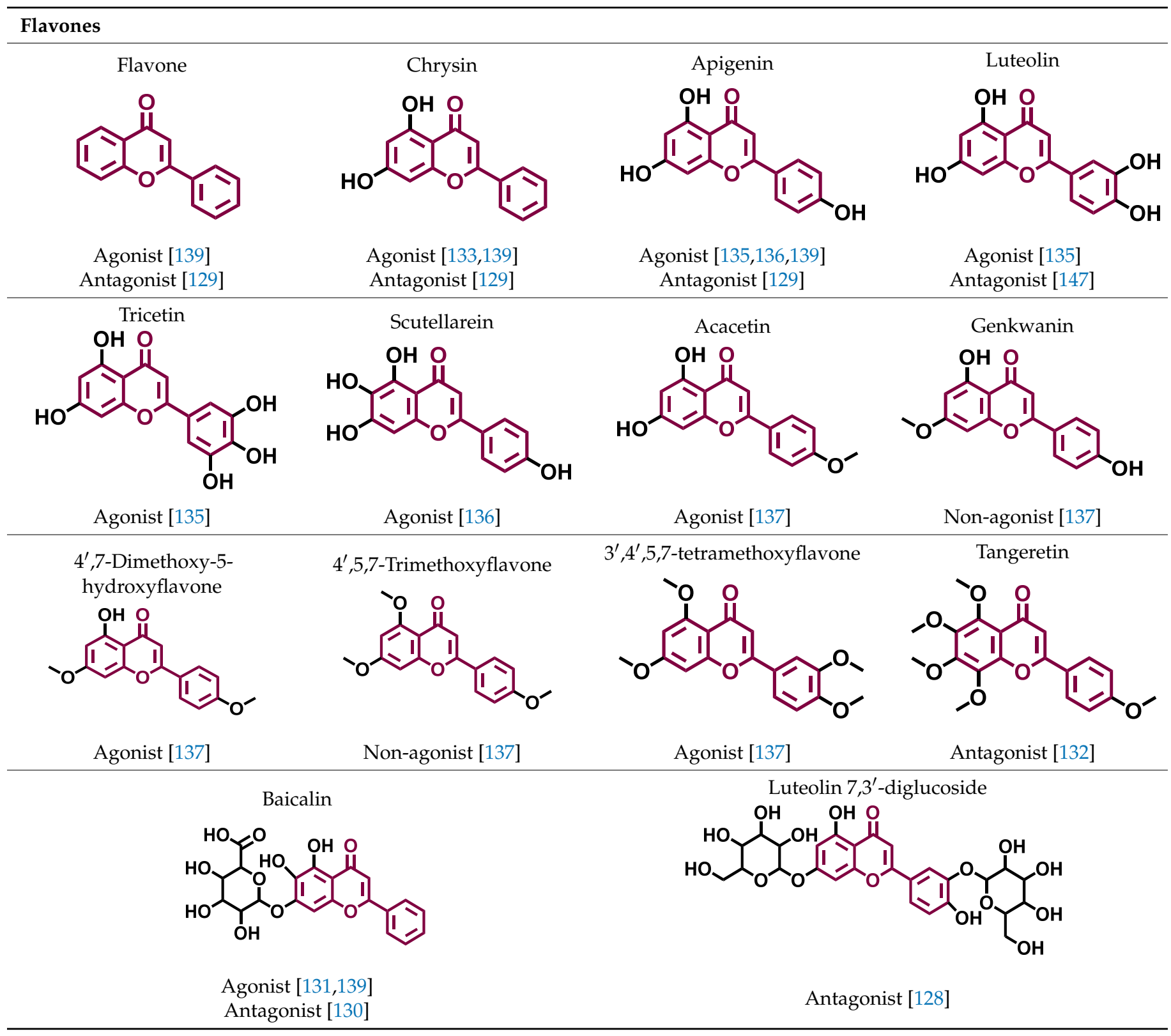


Table 3. Structures and AhR activity reported for the flavonol class of compounds.

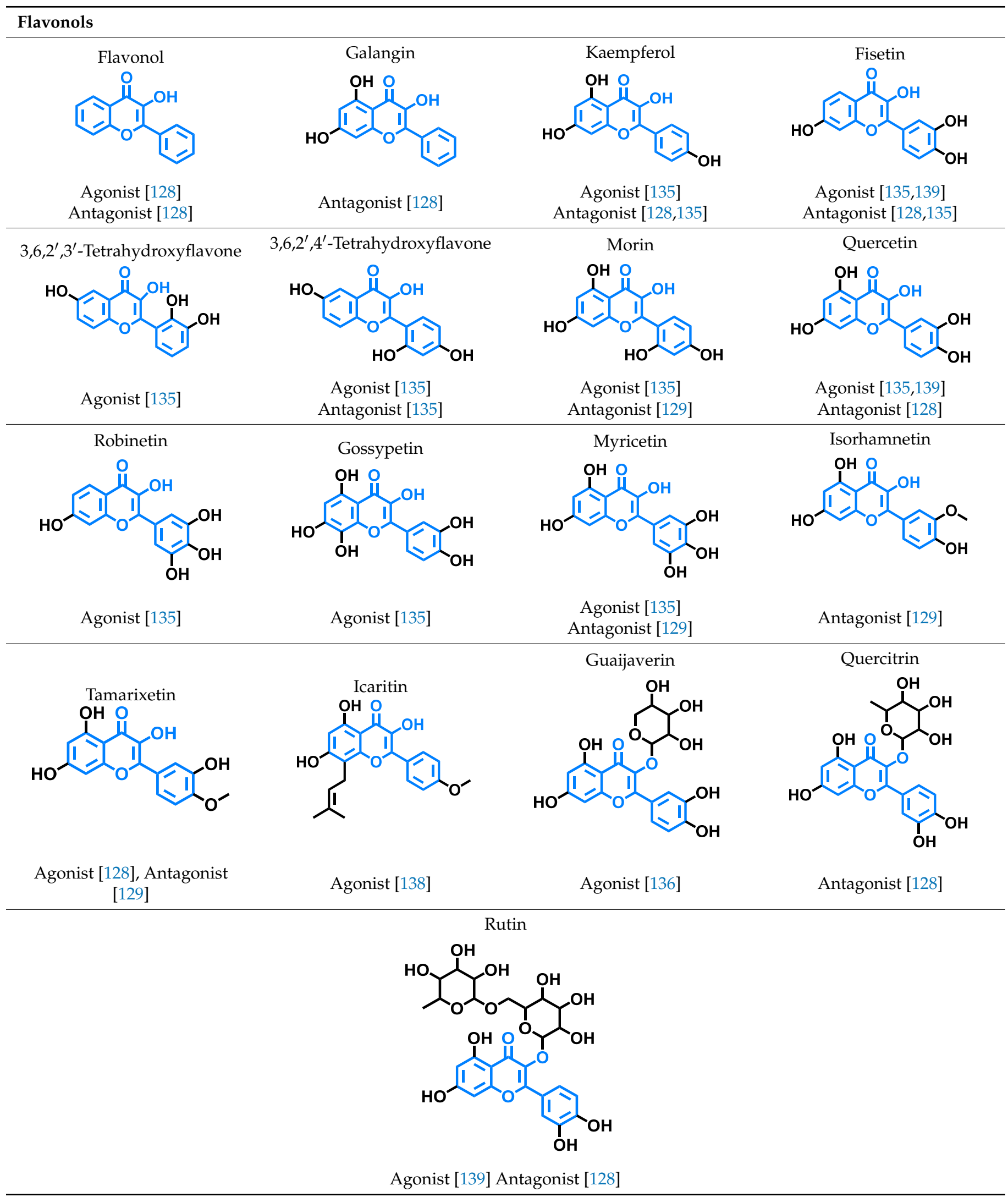


Molecules 2021, 26, 2315

12 of 20

Table 4. Structures and AR activity reported for the flavanone class of compounds.

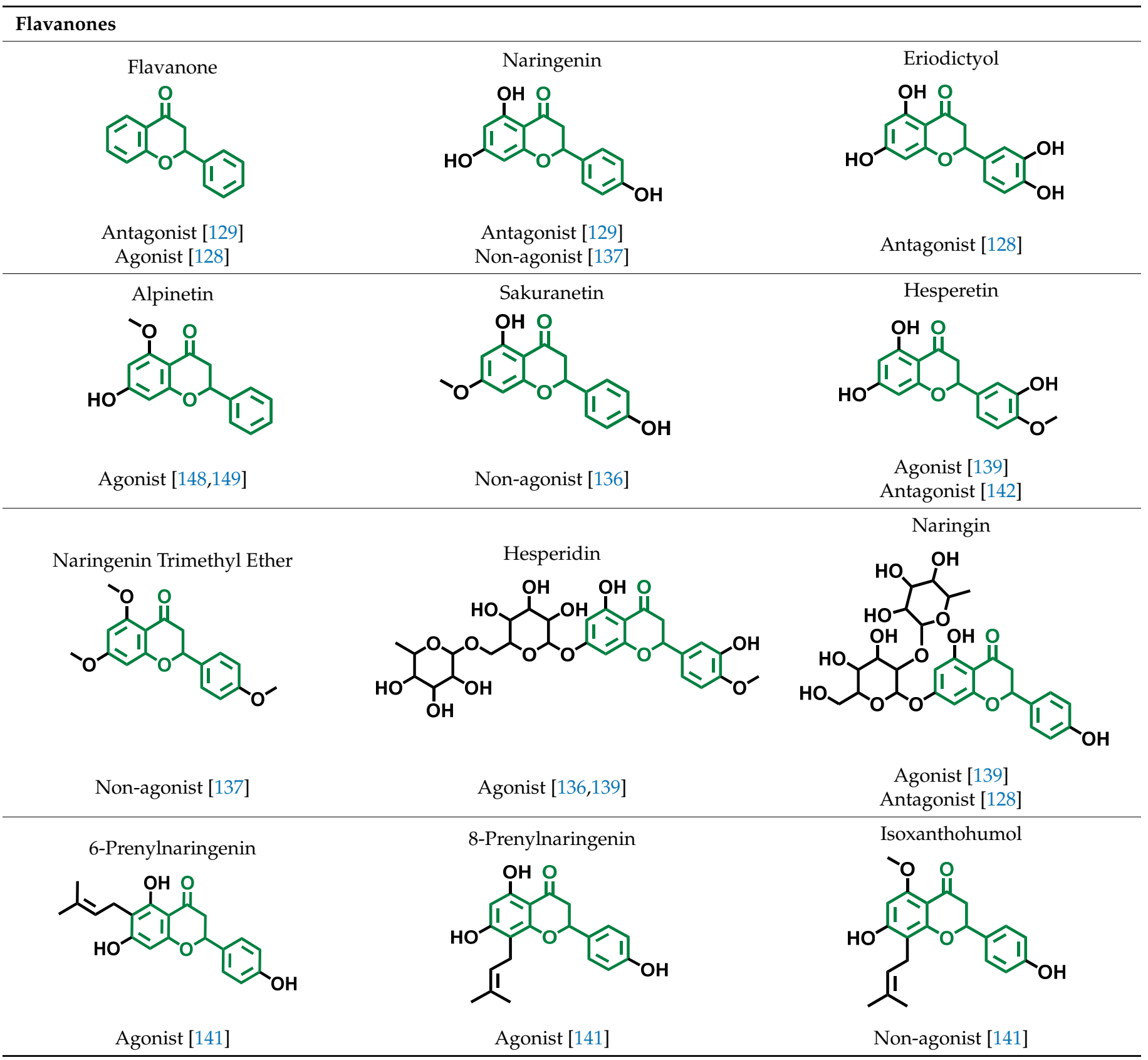

Table 5. Structures and AbR activity reported for the isoflavone class of compounds.

\begin{tabular}{c}
\hline Isoflavones \\
\hline Daidzein
\end{tabular}


Table 5. Cont.

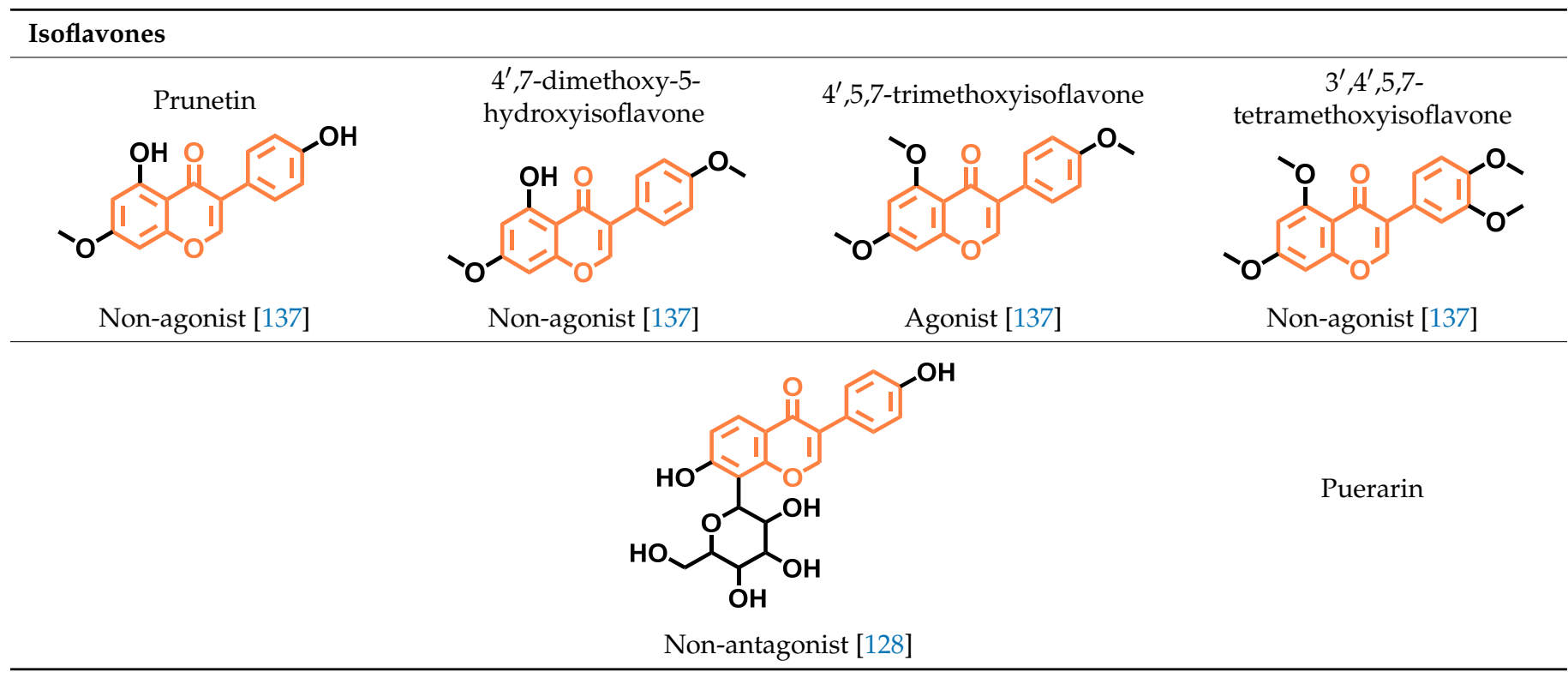

As shown in Tables 2-5, generalizations of structure-activity relationships are not possible when studying flavonoids as AhR modulators. AhR agonism and antagonism and, in many cases, both effects have been reported for flavones, flavonols, flavanones, and isoflavones. Nevertheless, the following patterns emerge.

1. The modulation of AhR by aglycones and glycosides analogous does not seem to differ significantly, noticeable when compare flavone luteolin vs. luteolin 7,3'-diglucoside (Table 2), that both display blockage effect on AhR transcriptional activation, although luteolin also exhibited agonist effects. In flavonols, the prototypical AhR modulator quercetin is reported as an agonist and as an antagonist of the receptor (Table 3), while its glycoside analogous guaijaverin is described as agonist, quercitrin as antagonist, and rutin has shown both agonist and antagonist effects. The flavanone aglycone hesperetin is reported as AhR antagonist, while exhibited also AhR agonist effects as the glycoside hesperidin. Naringenin differs from naringin in the agonist capacity, reported only for the glycoside derivative (Table 4).

2. Flavone and flavonol analogues (Tables 2 and 3) do not display substantial differences in their effects deduced when compare flavone vs. flavonol, apigenin vs. kaempferol, and luteolin vs. quercetin. Most of them have shown AhR agonism and AhR antagonism.

3. Comparing the flavone apigenin vs. the isoflavone analogous genistein, the modification from position 2 to position 3 appears to lead to the loss of agonist effects (Tables 2 and 5). Similarly, a loss of agonism is observed when compared to unsaturated analogous (apigenin and kaempferol) vs. the saturated flavanone naringenin (Tables 2-4).

4. The hydroxy-analogous derivatives representing the four classes of flavonoids: apigenin kaempferol, naringenin, and genistein have displayed AhR antagonist activity (Tables 2-5).

5. In flavone derivatives, the 7-methoxy substitution causes a loss of agonist capacity noticeable when compared genkwanin vs. the tri-hydroxy substituted apigenin (Table 2). In flavanones (naringenin vs. sakuranetin) (Table 4) and isoflavones (genistein vs. prunetin) (Table 5), 7-methoxy derivatives and 7-hydroxy derivatives are all reported as non-agonist of AhR. The 7-hydroxy flavanone naringenin and the 7-hydroxy isoflavone genistein have shown AhR antagonism.

6. The 4-methoxy substitution does not seem to affect the AhR agonist potential in flavones (acacetin vs. apigenin) (Table 2). 
7. In isoflavones, $4^{\prime}$-methoxy substitution confers AhR agonist activity (daidzein vs. formononetin and biochanin A vs. genistein) (Table 5).

8. Compounds 4',5,7-trimethoxy flavone (Table 2) and 4',5,7-trimethoxy flavanone (Table 4) both lack AhR agonist effects. However, the analogous 4',5,7-trimethoxy isoflavone (Table 5) is an AhR agonist.

9. The 4',7-dimethoxy substitution is positive for AhR agonism in flavones compared to $4^{\prime}, 5,7$-trimethoxy substitution (Table 2). The opposite occurs in isoflavones (Table 5).

10. The $3^{\prime}, 4^{\prime}, 5,7$-tetramethoxyflavone is AhR agonist (Table 2), but the analogous $3^{\prime}, 4^{\prime}, 5,7-$ tetramethoxyisoflavone does not activate the receptor (Table 5).

11. Most of the prenylated flavonoids are described as AhR agonists, such as the flavonol icaritin (Table 3) and the flavanones 6-prenylnaringenin and 8-prenylnaringenin (Table 4). However, this is not the case of the flavanone isoxanthohumol (Table 4).

Historically, the effect of flavonoids on AhR was associated with their capacity to suppress the receptor transcriptional activity [150]. However, as demonstrated in this review, the range of $\mathrm{AhR}$ agonist and antagonist effects of flavonoids have been shown to be much more complex and diverse than previously thought. The analysis of the structural substitution patterns of flavonoids does not appear to lead to general predictions of their potential AhR modulation. Differences in bioassays and experimental conditions and laboratories could be playing an important role in the AhR activity profile reported in the literature for flavonoids. Furthermore, as previously mentioned, several AhR, including some flavonoids, are considered to be SAhRMs. That is, the type of tissue and organ in which the AhR effects caused by these ligands are evaluated largely determines their behavior on the receptor $[19,151]$. Such selectivity on AhR could probably contribute to the therapeutical applicability of flavonoids as AhR mediators, as it has been suggested for the isoflavones biochanin A and formononetin used to ameliorate menopausal complaints [151]. However, the complexity and broad-based evidence required to ensure optimal ligand effects, in the absence of readily predictive AhR agonism and/or antagonism, is a matter that should be extensively studied. Therefore, further investigations on AhR transcriptional modulation caused by flavonoids need to be conducted in order to regulate their harmful consequences and get the most of their therapeutical potential through this pathway.

\section{Conclusions}

Despite several decades of research on flavonoid derivatives, these ubiquitous constituents of food remain surprising for their bioactivity profiles. AhR is a pleiotropic chemosensor with toxicological and pharmacological implications. Therefore, AhR modulation caused by flavonoids could impact several fields including food science, nutrition, drug discovery, agronomy, and environmental research. Basic research on AhR and its multiple modulators, including the diet-incorporated flavonoids, could provide useful premises to health care, adequate nutrition, and risk assessment in the translational science paradigm.

\section{Search Methodology}

The data collected in this review article aimed to concisely summarize the structural characteristics and functions of the transcription factor AhR (from 1990-2020), as well as to identify all plant flavonoids that have been evaluated as AhR modulators (from 20002020). The most common and accurate sources were used to run the search including the scientific databases PubMed, Scopus, Web of Science, Science Direct, and Google Scholar. Keywords used to carry out the search included "dioxin receptor", "ah receptor", "aryl hydrocarbon receptor", and "flavonoid". The search syntaxes for the different databases were considered. Results of the search strategies implemented independently by two researchers were contrasted. 
Author Contributions: Conceptualization, Investigation, Writing-original Draft, E.G.-J.; Investigation: Data/evidence collection, M.E.J.R.; Formal analysis \& SAR suggestions, M.S.-I.V.; Formal Analysis, Supervision, Project administration, R.M.G. All authors have read and agreed to the published version of the manuscript.

Funding: The preparation of this bibliographic review was financially supported by "PROTECTED" project (http: / protected.eu.com/), that has received funding from the European Union's Horizon 2020 research and innovation programme under the Marie Skłodowska-Curie grant agreement No. 722634.

Institutional Review Board Statement: Not applicable.

Informed Consent Statement: Not applicable.

Data Availability Statement: Not applicable.

Acknowledgments: Authors acknowledge the website SMART (Servier Medical Art) https:/ /smart. servier.com (accessed on 7 July 2020) for supplying some of the structures used in Figure 2.

Conflicts of Interest: The authors declare no conflict of interest.

\section{References}

1. Scarano, A.; Chieppa, M.; Santino, A. Looking at Flavonoid Biodiversity in Horticultural Crops: A Colored Mine with Nutritional Benefits. Plants 2018, 7, 98. [CrossRef] [PubMed]

2. Durazzo, A.; Lucarini, M.; Souto, E.B.; Cicala, C.; Caiazzo, E.; Izzo, A.A.; Novellino, E.; Santini, A. Polyphenols: A Concise Overview on the Chemistry, Occurrence, and Human Health. Phytother. Res. 2019, 33, 2221-2243. [CrossRef] [PubMed]

3. Panche, A.N.; Diwan, A.D.; Chandra, S.R. Flavonoids: An Overview. J. Nutr. Sci. 2016, 5, e47. [CrossRef] [PubMed]

4. Gonzales, G.B. In Vitro Bioavailability and Cellular Bioactivity Studies of Flavonoids and Flavonoid-Rich Plant Extracts: Questions, Considerations and Future Perspectives. Proc. Nutr. Soc. 2017, 76, 175-181. [CrossRef] [PubMed]

5. Ginwala, R.; Bhavsar, R.; Chigbu, D.I.; Jain, P.; Khan, Z.K. Potential Role of Flavonoids in Treating Chronic Inflammatory Diseases with a Special Focus on the Anti-Inflammatory Activity of Apigenin. Antioxidants 2019, 8, 35. [CrossRef]

6. Perez-Vizcaino, F.; Fraga, C.G. Research Trends in Flavonoids and Health. Arch. Biochem. Biophys. 2018, 646, 107-112. [CrossRef]

7. Procházková, D.; Boušová, I.; Wilhelmová, N. Antioxidant and Prooxidant Properties of Flavonoids. Fitoterapia 2011, 82, 513-523. [CrossRef]

8. Nebert, D.W. Aryl Hydrocarbon Receptor (AHR): “Pioneer Member" of the Basic-Helix/Loop/Helix per-Arnt-Sim (BHLH/PAS) Family of "Sensors" of Foreign and Endogenous Signals. Prog. Lipid Res. 2017, 67, 38-57. [CrossRef]

9. Bock, K.W. From TCDD-Mediated Toxicity to Searches of Physiologic AHR Functions. Biochem. Pharmacol. 2018, 155, 419-424. [CrossRef]

10. Okey, A.B. An Aryl Hydrocarbon Receptor Odyssey to the Shores of Toxicology: The Deichmann Lecture, International Congress of Toxicology-XI. Toxicol. Sci. 2007, 98, 5-38. [CrossRef]

11. Yang, T.; Feng, Y.; Chen, L.; Vaziri, N.D.; Zhao, Y.; Yang, T.; Feng, Y.; Chen, L.; Vaziri, N.D.; Zhao, Y. Dietary Natural Flavonoids Treating Cancer by Targeting Aryl Hydrocarbon Receptor. Crit. Rev. Toxicol. 2019, 49, 445-460. [CrossRef]

12. Esser, C.; Lawrence, B.P.; Sherr, D.H.; Perdew, G.H.; Puga, A.; Barouki, R.; Coumoul, X. Old Receptor, New Tricks-The EverExpanding Universe of Aryl Hydrocarbon Receptor Functions. Report from the 4th AHR Meeting, 29-31 August 2018 in Paris, France. Int. J. Mol. Sci. 2018, 19, 3603. [CrossRef] [PubMed]

13. Goya-Jorge, E.; Abdmouleh, F.; Carpio, L.E.; Giner, R.M.; Sylla-Iyarreta Veitía, M. Discovery of 2-Aryl and 2-Pyridinylbenzothiazoles Endowed with Antimicrobial and Aryl Hydrocarbon Receptor Agonistic Activities. Eur. J. Pharm. Sci. 2020, $151,105386$. [CrossRef] [PubMed]

14. Goya-Jorge, E.; Doan, T.Q.; Scippo, M.L.; Muller, M.; Giner, R.M.; Barigye, S.J.; Gozalbes, R. Elucidating the Aryl Hydrocarbon Receptor Antagonism from a Chemical-Structural Perspective. SAR QSAR Environ. Res. 2020, 31. [CrossRef] [PubMed]

15. Goya-Jorge, E.; Rampal, C.; Loones, N.; Barigye, S.J.; Carpio, L.E.; Gozalbes, R.; Ferroud, C.; Veitía, M.S.-I.; Giner, R.M. Targeting the Aryl Hydrocarbon Receptor with a Novel Set of Triarylmethanes. Eur. J. Med. Chem. 2020, 207, 112777. [CrossRef] [PubMed]

16. Amakura, Y.; Tsutsumi, T.; Nakamura, M.; Handa, H.; Yoshimura, M.; Matsuda, R.; Yoshida, T. Aryl Hydrocarbon Receptor Ligand Activity of Commercial Health Foods. Food Chem. 2011, 126, 1515-1520. [CrossRef]

17. Xue, Z.; Li, D.; Yu, W.; Zhang, Q.; Hou, X.; He, Y.; Kou, X. Mechanisms and Therapeutic Prospects of Polyphenols as Modulators of the Aryl Hydrocarbon Receptor. Food Funct. 2017, 8, 1414-1437. [CrossRef] [PubMed]

18. Ciolino, H.P.; Daschner, P.J.; Yeh, G.C. Dietary Flavonols Quercetin and Kaempferol Are Ligands of the Aryl Hydrocarbon Receptor That Affect CYP1A1 Transcription Differentially. Biochem. J. 1999, 340, 715-722. [CrossRef]

19. Safe, S.; Jin, U.H.; Park, H.; Chapkin, R.S.; Jayaraman, A. Aryl Hydrocarbon Receptor (AHR) Ligands as Selective Ahr Modulators (SAHRMS). Int. J. Mol. Sci. 2020, 21, 6654. [CrossRef] [PubMed]

20. Carver, L.A.; Hogenesch, J.B.; Bradfield, C.A. Tissue Specific Expression of the Rat Ah-Receptor and ARNT MRNAs. Nucleic Acids Res. 1994, 22, 3038-3044. [CrossRef] 
21. Murray, I.A.; Patterson, A.D.; Perdew, G.H. Aryl Hydrocarbon Receptor Ligands in Cancer: Friend and Foe. Nat. Rev. Cancer 2014, 14, 801-814. [CrossRef] [PubMed]

22. Hogenesch, J.B.; Chan, W.K.; Jackiw, V.H.; Brown, R.C.; Gu, Y.Z.; Pray-Grant, M.; Perdew, G.H.; Bradfield, C.A. Characterization of a Subset of the Basic-Helix-Loop-Helix-PAS Superfamily That Interacts with Components of the Dioxin Signaling Pathway. J. Biol. Chem. 1997, 272, 8581-8593. [CrossRef] [PubMed]

23. Larigot, L.; Juricek, L.; Dairou, J.; Coumoul, X. AhR Signaling Pathways and Regulatory Functions. Biochim. Open 2018, 7, 1-9. [CrossRef] [PubMed]

24. Kewley, R.J.; Whitelaw, M.L.; Chapman-Smith, A. The Mammalian Basic Helix-Loop-Helix/PAS Family of Transcriptional Regulators. Int. J. Biochem. Cell Biol. 2004, 36, 189-204. [CrossRef]

25. Schulte, K.W.; Green, E.; Wilz, A.; Platten, M.; Daumke, O. Structural Basis for Aryl Hydrocarbon Receptor-Mediated Gene Activation. Structure 2017, 25, 1025-1033.e3. [CrossRef] [PubMed]

26. Kumar, M.B.; Ramadoss, P.; Reen, R.K.; vanden Heuvel, J.P.; Perdew, G.H. The Q-Rich Subdomain of the Human Ah Receptor Transactivation Domain Is Required for Dioxin-Mediated Transcriptional Activity. J. Biol. Chem. 2001, 276, 42302-42310. [CrossRef]

27. Hankinson, O. Role of Coactivators in Transcriptional Activation by the Aryl Hydrocarbon Receptor. Arch. Biochem. Biophys. 2005, 433, 379-386. [CrossRef] [PubMed]

28. Pratt, W.B.; Galigniana, M.D.; Harrell, J.M.; DeFranco, D.B. Role of Hsp90 and the Hsp90-Binding Immunophilins in Signalling Protein Movement. Cell. Signal. 2004, 16, 857-872. [CrossRef]

29. Bell, D.R.; Poland, A. Binding of Aryl Hydrocarbon Receptor (AhR) to AhR-Interacting Protein: The Role of Hsp90. J. Biol. Chem. 2000, 275, 36407-36414. [CrossRef] [PubMed]

30. Young, J.C.; Moarefi, I.; Ulrich Hartl, F. Hsp90: A Specialized but Essential Protein-Folding Tool. J. Cell Biol. 2001, 154, 267-273. [CrossRef]

31. Cox, M.B.; Miller, C.A., III. The P23 Co-Chaperone Facilitates Dioxin Receptor Signaling in a Yeast Model System. Toxicol. Lett. 2002, 129, 13-21. [CrossRef]

32. Shetty, P.V.; Bhagwat, B.Y.; Chan, W.K. P23 Enhances the Formation of the Aryl Hydrocarbon Receptor-DNA Complex. Biochem. Pharmacol. 2003, 65, 941-948. [CrossRef]

33. Pappas, B.; Yang, Y.; Wang, Y.; Kim, K.; Chung, H.J.; Cheung, M.; Ngo, K.; Shinn, A.; Chan, W.K. P23 Protects the Human Aryl Hydrocarbon Receptor from Degradation via a Heat Shock Protein 90-Independent Mechanism. Biochem. Pharmacol. 2018, 152, 34-44. [CrossRef] [PubMed]

34. Meyer, B.K.; Perdew, G.H. Characterization of the AhR-Hsp90-XAP2 Core Complex and the Role of the Immunophilin-Related Protein XAP2 in AhR Stabilization. Biochemistry 1999, 38, 8907-8917. [CrossRef] [PubMed]

35. Carver, L.A.; Lapres, J.J.; Jain, S.; Dunham, E.E.; Bradfield, C.A. Characterization of the Ah Receptor-Associated Protein, ARA9. J. Biol. Chem. 1998, 273, 33580-33587. [CrossRef] [PubMed]

36. Meyer, B.K.; Petrulis, J.R.; Perdew, G.H. Aryl Hydrocarbon (Ah) Receptor Levels Are Selectively Modulated by Hsp90-Associated Immunophilin Homolog XAP2. Cell Stress Chaperones 2000, 5, 243-254. [CrossRef]

37. Dong, B.; Cheng, W.; Li, W.; Zheng, J.; Wu, D.; Matsumura, F.; Vogel, C.F.A. FRET Analysis of Protein Tyrosine Kinase C-Src Activation Mediated via Aryl Hydrocarbon Receptor. Biochim. Et Biophys. Acta (BBA) Gen. Subj. 2011, 1810, 427-431. [CrossRef]

38. Ikuta, T.; Eguchi, H.; Tachibana, T.; Yoneda, Y.; Kawajiri, K. Nuclear Localization and Export Signals of the Human Aryl Hydrocarbon Receptor. J. Biol. Chem. 1998, 273, 2895-2904. [CrossRef]

39. Ikuta, T.; Kobayashi, Y.; Kawajiri, K. Phosphorylation of Nuclear Localization Signal Inhibits the Ligand-Dependent Nuclear Import of Aryl Hydrocarbon Receptor. Biochem. Biophys. Res. Commun. 2004, 317, 545-550. [CrossRef]

40. Enan, E.; Matsumura, F. Identification of C-Src as the Integral Component of the Cytosolic Ah Receptor Complex, Transducing the Signal of 2,3,7,8-Tetrachlorodibenzo-p-Dioxin (TCDD) through the Protein Phosphorylation Pathway. Biochem. Pharmacol. 1996, 52, 1599-1612. [CrossRef]

41. Petrulis, J.R.; Kusnadi, A.; Ramadoss, P.; Hollingshead, B.; Perdew, G.H. The Hsp90 Co-Chaperone XAP2 Alters Importin $\beta$ Recognition of the Bipartite Nuclear Localization Signal of the Ah Receptor and Represses Transcriptional Activity. J. Biol. Chem. 2003, 278, 2677-2685. [CrossRef]

42. Hoffman, E.C.; Reyes, H.; Chu, F.F.; Sander, F.; Conley, L.H.; Brooks, B.A.; Hankinson, O. Cloning of a Factor Required for Activity of the Ah (Dioxin) Receptor. Science 1991, 252, 954-958. [CrossRef]

43. Swanson, H.I.; Tullis, K.; Denison, M.S. Binding of Transformed Ah Receptor Complex to a Dioxin Responsive Transcriptional Enhancer: Evidence for Two Distinct Heteromeric DNA-Binding Forms. Biochemistry 1993, 32, 12841-12849. [CrossRef]

44. Wright, E.J.; de Castro, K.P.; Joshi, A.D.; Elferink, C.J. Canonical and Non-Canonical Aryl Hydrocarbon Receptor Signaling Pathways Toxicology. Curr. Opin. Toxicol. 2017, 2, 87-92. [CrossRef] [PubMed]

45. Yao, E.F.; Denison, M.S. DNA Sequence Determinants for Binding of Transformed Ah Receptor to a Dioxin-Responsive Enhancer. Biochemistry 1992, 31, 5060-5067. [CrossRef]

46. Sakurai, S.; Shimizu, T.; Ohto, U. The Crystal Structure of the AhRR-ARNT Heterodimer Reveals the Structural Basis of the Repression of AhR-Mediated Transcription. J. Biol. Chem. 2017, 292, 17609-17616. [CrossRef] [PubMed]

47. Hahn, M.E.; Allan, L.L.; Sherr, D.H. Regulation of Constitutive and Inducible AHR Signaling: Complex Interactions Involving the AHR Repressor. Biochem. Pharmacol. 2009, 77, 485-497. [CrossRef] 
48. Vogel, C.F.A.; Ishihara, Y.; Campbell, C.E.; Kado, S.Y.; Nguyen-Chi, A.; Sweeney, C.; Pollet, M.; Stemmann, T.H.; Tuscano, J.M. A Protective Role of Aryl Hydrocarbon Receptor Repressor in Inflammation and Tumor Growth. Cancers 2019, 11, 589. [CrossRef]

49. Mimura, J.; Ema, M.; Sogawa, K.; Fujii-Kuriyama, Y. Identification of a Novel Mechanism of Regulation of Ah (Dioxin) Receptor Function. Genes Dev. 1999, 13, 20-25. [CrossRef]

50. Kress, S.; Reichert, J.; Schwarz, M. Functional Analysis of the Human Cytochrome P4501A1 (CYP1A1) Gene Enhancer. Eur. J. Biochem. 1998, 258, 803-812. [CrossRef] [PubMed]

51. Quattrochi, L.C.; Tukey, R.H. Nuclear Uptake of the Ah (Dioxin) Receptor in Response to Omeprazole: Transcriptional Activation of the Human CYP1A1 Gene. Mol. Pharmacol. 1993, 43, 504-508.

52. Ye, W.; Chen, R.; Chen, X.; Huang, B.; Lin, R.; Xie, X.; Chen, J.; Jiang, J.; Deng, Y.; Wen, J. AhR Regulates the Expression of Human Cytochrome P450 1A1 (CYP1A1) by Recruiting Sp1. FEBS J. 2019, 286, 4215-4231. [CrossRef] [PubMed]

53. Auyeung, D.J.; Kessler, F.K.; Ritter, J.K. Mechanism of Rat UDP-Glucuronosyltransferase 1A6 Induction by Oltipraz: Evidence for a Contribution of the AryL Hydrocarbon Receptor Pathway. Mol. Pharmacol. 2003, 63, 119-127. [CrossRef]

54. Hankinson, O. The Role of AHR-Inducible Cytochrome P450s in Metabolism of Polyunsaturated Fatty Acids. Drug Metab. Rev. 2016, 48, 342-350. [CrossRef] [PubMed]

55. Denison, M.S.; Soshilov, A.A.; He, G.; Degroot, D.E.; Zhao, B. Exactly the Same but Different: Promiscuity and Diversity in the Molecular Mechanisms of Action of the Aryl Hydrocarbon (Dioxin) Receptor. Toxicol. Sci. 2011, 124, 1-22. [CrossRef]

56. Wilson, S.R.; Joshi, A.D.; Elferink, C.J. The Tumor Suppressor Kruppel-like Factor 6 Is a Novel Aryl Hydrocarbon Receptor DNA Binding Partner. J. Pharmacol. Exp. Ther. 2013, 345, 419-429. [CrossRef]

57. Biscardi, J.S.; Maa, M.C.; Tice, D.A.; Cox, M.E.; Leu, T.H.; Parsons, S.J. C-Src-Mediated Phosphorylation of the Epidermal Growth Factor Receptor on Tyr845 and Tyr1101 Is Associated with Modulation of Receptor Function. J. Biol. Chem. 1999, 274, 8335-8343. [CrossRef] [PubMed]

58. Haarmann-Stemmann, T.; Bothe, H.; Abel, J. Growth Factors, Cytokines and Their Receptors as Downstream Targets of Arylhydrocarbon Receptor (AhR) Signaling Pathways. Biochem. Pharmacol. 2009, 77, 508-520. [CrossRef]

59. Yu, A.R.; Jeong, Y.J.; Hwang, C.Y.; Yoon, K.S.; Choe, W.; Ha, J.; Kim, S.S.; Pak, Y.K.; Yeo, E.J.; Kang, I. Alpha-Naphthoflavone Induces Apoptosis through Endoplasmic Reticulum Stress via c-Src-, ROS-, MAPKs-, and Arylhydrocarbon Receptor-Dependent Pathways in HT22 Hippocampal Neuronal Cells. Neurotoxicology 2019, 71, 39-51. [CrossRef] [PubMed]

60. Domínguez-Acosta, O.; Vega, L.; Estrada-Muñiz, E.; Rodríguez, M.S.; Gonzalez, F.J.; Elizondo, G. Activation of Aryl Hydrocarbon Receptor Regulates the LPS/IFN\$ \$-Induced Inflammatory Response by Inducing Ubiquitin-Proteosomal and Lysosomal Degradation of RelA/P65. Biochem. Pharmacol. 2018, 155, 141-149. [CrossRef]

61. Mejía-García, A.; González-Barbosa, E.; Martínez-Guzmán, C.; Torres-Ramos, M.A.; Rodríguez, M.S.; Guzmán-León, S.; Elizondo, G. Activation of AHR Mediates the Ubiquitination and Proteasome Degradation of C-Fos through the Induction of Ubcm4 Gene Expression. Toxicology 2015, 337, 47-57. [CrossRef] [PubMed]

62. Ohtake, F.; Fujii-Kuriyama, Y.; Kato, S. AhR Acts as an E3 Ubiquitin Ligase to Modulate Steroid Receptor Functions. Biochem. Pharmacol. 2009, 77, 474-484. [CrossRef] [PubMed]

63. Ohtake, F.; Baba, A.; Takada, I.; Okada, M.; Iwasaki, K.; Miki, H.; Takahashi, S.; Kouzmenko, A.; Nohara, K.; Chiba, T.; et al. Dioxin Receptor Is a Ligand-Dependent E3 Ubiquitin Ligase. Nature 2007, 446, 562-566. [CrossRef] [PubMed]

64. Matsumura, F. The Significance of the Nongenomic Pathway in Mediating Inflammatory Signaling of the Dioxin-Activated Ah Receptor to Cause Toxic Effects. Biochem. Pharmacol. 2009, 77, 608-626. [CrossRef]

65. Puga, A.; Ma, C.; Marlowe, J.L. The Aryl Hydrocarbon Receptor Cross-Talks with Multiple Signal Transduction Pathways. Biochem. Pharmacol. 2009, 77, 713-722. [CrossRef]

66. Roman, Á.C.; Carvajal-Gonzalez, J.M.; Merino, J.M.; Mulero-Navarro, S.; Fernández-Salguero, P.M. The Aryl Hydrocarbon Receptor in the Crossroad of Signalling Networks with Therapeutic Value. Pharmacol. Ther. 2018, 185, 50-63. [CrossRef]

67. Ohtake, F.; Takeyama, K.-I.; Matsumoto, T.; Kitagawa, H.; Yamamoto, Y.; Nohara, K.; Tohyama, C.; Krust, A.; Mimura, J.; Chambon, P.; et al. Modulation of Oestrogen Receptor Signalling by Association with the Activated Dioxin Receptor. Nature 2003, 423, 545-550. [CrossRef]

68. Mathew, L.K.; Sengupta, S.S.; LaDu, J.; Andreasen, E.A.; Tanguay, R.L. Crosstalk between AHR and Wnt Signaling through R-Spondin1 Impairs Tissue Regeneration in Zebrafish. FASEB J. 2008, 22, 3087-3096. [CrossRef]

69. Chassot, A.A.; Bradford, S.T.; Auguste, A.; Gregoire, E.P.; Pailhoux, E.; de Rooij, D.G.; Schedl, A.; Chaboissier, M.C. WNT4 and RSPO1 Together Are Required for Cell Proliferation in the Early Mouse Gonad. Development 2012, 139, 4461-4472. [CrossRef]

70. Tomaselli, S.; Megiorni, F.; Lin, L.; Mazzilli, M.C.; Gerrelli, D.; Majore, S.; Grammatico, P.; Achermann, J.C. Human RSPO1/RSpondin1 Is Expressed during Early Ovary Development and Augments $\beta$-Catenin Signaling. PLoS ONE 2011, 6, e16366. [CrossRef]

71. Komiya, Y.; Habas, R. Wnt Signal Transduction Pathways. Organogenesis 2008, 4, 68-75. [CrossRef]

72. Neuzillet, C.; Tijeras-Raballand, A.; Cohen, R.; Cros, J.; Faivre, S.; Raymond, E.; De Gramont, A. Targeting the TGF $\beta$ Pathway for Cancer Therapy. Pharmacol. Ther. 2015, 147, 22-31. [CrossRef] [PubMed]

73. Ishihara, Y.; Kado, S.Y.; Hoeper, C.; Harel, S.; Vogel, C.F.A. Role of NF-KB RelB in Aryl Hydrocarbon Receptor-Mediated Ligand Specific Effects. Int. J. Mol. Sci. 2019, 20, 2652. [CrossRef]

74. Vogel, C.F.A.; Sciullo, E.; Li, W.; Wong, P.; Lazennec, G.; Matsumura, F. RelB, a New Partner of Aryl Hydrocarbon ReceptorMediated Transcription. Mol. Endocrinol. 2007, 21, 2941-2955. [CrossRef] [PubMed] 
75. Pollenz, R.S. The Mechanism of AH Receptor Protein Down-Regulation (Degradation) and Its Impact on AH Receptor-Mediated Gene Regulation. Chem. Biol. Interact. 2002, 141, 41-61. [CrossRef]

76. Pollenz, R.S.; Barbour, E.R. Analysis of the Complex Relationship between Nuclear Export and Aryl Hydrocarbon ReceptorMediated Gene Regulation. Mol. Cell. Biol. 2000, 20, 6095-6104. [CrossRef] [PubMed]

77. Chen, J.; Yang, Y.; Russu, W.A.; Chan, W.K. The Aryl Hydrocarbon Receptor Undergoes Chaperone-Mediated Autophagy in Triple-Negative Breast Cancer Cells. Int. J. Mol. Sci. 2021, 22, 1654. [CrossRef] [PubMed]

78. Rothhammer, V.; Quintana, F.J. The Aryl Hydrocarbon Receptor: An Environmental Sensor Integrating Immune Responses in Health and Disease. Nat. Rev. Immunol. 2019, 19, 184-197. [CrossRef]

79. Lamas, B.; Natividad, J.M.; Sokol, H. Aryl Hydrocarbon Receptor and Intestinal Immunity. Mucosal Immunol. 2018, 11, 1024-1038. [CrossRef]

80. Gao, J.; Xu, K.; Liu, H.; Liu, G.; Bai, M.; Peng, C.; Li, T.; Yin, Y. Impact of the Gut Microbiota on Intestinal Immunity Mediated by Tryptophan Metabolism. Front. Cell. Infect. Microbiol. 2018, 8, 1-22. [CrossRef] [PubMed]

81. Mitchell, K.A.; Elferink, C.J. Timing Is Everything: Consequences of Transient and Sustained AhR Activity. Biochem. Pharmacol. 2009, 77, 947-956. [CrossRef]

82. Mescher, M.; Haarmann-Stemmann, T. Modulation of CYP1A1 Metabolism: From Adverse Health Effects to Chemoprevention and Therapeutic Options. Pharmacol. Ther. 2018, 187, 71-87. [CrossRef]

83. Guerrina, N.; Traboulsi, H.; Eidelman, D.H.; Baglole, C.J. The Aryl Hydrocarbon Receptor and the Maintenance of Lung Health. Int. J. Mol. Sci. 2018, 19, 3882. [CrossRef]

84. Bock, K.W. Human AHR Functions in Vascular Tissue: Pro- and Anti-Inflammatory Responses of AHR Agonists in Atherosclerosis. Biochem. Pharmacol. 2019, 159, 116-120. [CrossRef]

85. Duval, C.; Blanc, E.; Coumoul, X. Aryl Hydrocarbon Receptor and Liver Fibrosis. Curr. Opin. Toxicol. 2018, 8, 8-13. [CrossRef]

86. Puccetti, M.; Paolicelli, G.; Oikonomou, V.; de Luca, A.; Renga, G.; Borghi, M.; Pariano, M.; Stincardini, C.; Scaringi, L.; Giovagnoli, S.; et al. Towards Targeting the Aryl Hydrocarbon Receptor in Cystic Fibrosis. Mediat. Inflamm. 2018, $2018,1601486$. [CrossRef]

87. Dietrich, C. Antioxidant Functions of the Aryl Hydrocarbon Receptor. Stem Cells Int. 2016, 2016. [CrossRef] [PubMed]

88. Juricek, L.; Coumoul, X. The Aryl Hydrocarbon Receptor and the Nervous System. Int. J. Mol. Sci. 2018, 19, 2504. [CrossRef]

89. Stejskalova, L.; Dvorak, Z.; Pavek, P. Endogenous and Exogenous Ligands of Aryl Hydrocarbon Receptor: Current State of Art. Curr. Drug Metab. 2011, 12, 198-212. [CrossRef] [PubMed]

90. Rannug, A.; Rannug, U.; Rosenkranz, H.S.; Winqvist, L.; Westerholm, R.; Agurell, E.; Grafström, A.K. Certain Photooxidized Derivatives of Tryptophan Bind with Very High Affinity to the Ah Receptor and Are Likely to Be Endogenous Signal Substances. J. Biol. Chem. 1987, 262, 15422-15427. [CrossRef]

91. Manzella, C.; Singhal, M.; Alrefai, W.A.; Saksena, S.; Dudeja, P.K.; Gill, R.K. Serotonin Is an Endogenous Regulator of Intestinal CYP1A1 via AhR. Sci. Rep. 2018, 8, 6103. [CrossRef]

92. Seok, S.-H.; Lee, W.; Jiang, L.; Molugu, K.; Zheng, A.; Li, Y.; Park, S.; Bradfield, C.A.; Xing, Y. Structural Hierarchy Controlling Dimerization and Target DNA Recognition in the AHR Transcriptional Complex. Proc. Natl. Acad. Sci. USA 2017, 114, 5431-5436. [CrossRef]

93. Zhou, H.; Wu, H.; Liao, C.; Diao, X.; Zhen, J.; Chen, L.; Xue, Q. Toxicology Mechanism of the Persistent Organic Pollutants (POPs) in Fish through AhR Pathway. Toxicol. Mech. Methods 2010, 20, 279-286. [CrossRef]

94. Esser, C.; Rannug, A.; Stockinger, B. The Aryl Hydrocarbon Receptor in Immunity. Trends Immunol. 2009, 30, 447-454. [CrossRef] [PubMed]

95. Marafini, I.; Di Fusco, D.; Dinallo, V.; Franzè, E.; Stolfi, C.; Sica, G.; Monteleone, G.; Monteleone, I. NPD-0414-2 and NPD0414-24, Two Chemical Entities Designed as Aryl Hydrocarbon Receptor (AHR) Ligands, Inhibit Gut Inflammatory Signals. Front. Pharmacol. 2019, 10, 1-9. [CrossRef] [PubMed]

96. Bradshaw, T.; Westwell, A. The Development of the Antitumour Benzothiazole Prodrug, Phortress, as a Clinical Candidate. Curr. Med. Chem. 2005, 11, 1009-1021. [CrossRef]

97. Loaiza-Pérez, A.I.; Kenney, S.; Boswell, J.; Hollingshead, M.; Alley, M.C.; Hose, C.; Ciolino, H.P.; Yeh, G.C.; Trepel, J.B.; Vistica, D.T.; et al. Aryl Hydrocarbon Receptor Activation of an Antitumor Aminoflavone: Basis of Selective Toxicity for MCF-7 Breast Tumor Cells. Mol. Cancer Ther. 2004, 3, 715-725.

98. Mozaffarian, D.; Wu, J.H.Y. Flavonoids, Dairy Foods, and Cardiovascular and Metabolic Health: A Review of Emerging Biologic Pathways. Circ. Res. 2018, 122, 369-384. [CrossRef]

99. Scarmeas, N.; Anastasiou, C.A.; Yannakoulia, M. Nutrition and Prevention of Cognitive Impairment. Lancet Neurol. 2018, 17, 1006-1015. [CrossRef]

100. Agati, G.; Tattini, M. Multiple Functional Roles of Flavonoids in Photoprotection. New Phytol. 2010, 186, 786-793. [CrossRef] [PubMed]

101. Lattanzio, V. Phenolic Compounds: Introduction. In Natural Products: Phytochemistry, Botany and Metabolism of Alkaloids, Phenolics and Terpenes; Ramawat, K.G., Mérillon, J.-M., Eds.; Springer: Berlin/Heidelberg, Germany, 2013; pp. 1543-1580, ISBN 978-3-64222144-6.

102. Abbas, M.; Saeed, F.; Anjum, F.M.; Afzaal, M.; Tufail, T.; Bashir, M.S.; Ishtiaq, A.; Hussain, S.; Suleria, H.A.R. Natural Polyphenols: An Overview. Int. J. Food Prop. 2017, 20, 1689-1699. [CrossRef] 
103. Pandey, R.P.; Sohng, J.K. Genetics of Flavonoids. In Natural Products: Phytochemistry, Botany and Metabolism of Alkaloids, Phenolics and Terpenes; Ramawat, K.G., Mérillon, J.-M., Eds.; Springer: Berlin/Heidelberg, Germany, 2013; pp. 1617-1645, ISBN 978-3-64222144-6.

104. Abotaleb, M.; Samuel, S.M.; Varghese, E.; Varghese, S.; Kubatka, P.; Liskova, A.; Büsselberg, D. Flavonoids in Cancer and Apoptosis. Cancers 2019, 11, 28. [CrossRef] [PubMed]

105. Forkmann, G.; Heller, W. 1.26 Biosynthesis of Flavonoids. In Comprehensive Natural Products Chemistry; Barton, S.D., Nakanishi, K., Meth-Cohn, O., Eds.; Pergamon: Oxford, UK, 1999; pp. 713-748, ISBN 978-0-08-091283-7.

106. Teng, H.; Chen, L. Polyphenols and Bioavailability: An Update. Crit. Rev. Food Sci. Nutr. 2019, 59, 2040-2051. [CrossRef] [PubMed]

107. Cermak, R.; Durazzo, A.; Maiani, G.; Böhm, V.; Kammerer, D.R.; Carle, R.; Wiczkowski, W.; Piskula, M.K.; Galensa, R. The Influence of Postharvest Processing and Storage of Foodstuffs on the Bioavailability of Flavonoids and Phenolic Acids. Mol. Nutr. Food Res. 2009, 53, S184-S193. [CrossRef] [PubMed]

108. Tungmunnithum, D.; Thongboonyou, A.; Pholboon, A.; Yangsabai, A. Flavonoids and Other Phenolic Compounds from Medicinal Plants for Pharmaceutical and Medical Aspects: An Overview. Medicines 2018, 5, 93. [CrossRef]

109. Quideau, S.; Deffieux, D.; Douat-Casassus, C.; Pouységu, L. Plant Polyphenols: Chemical Properties, Biological Activities, and Synthesis. Angew. Chem. Int. Ed. 2011, 50, 586-621. [CrossRef]

110. Xie, Y.; Huang, S.; Su, Y. Dietary Flavonols Intake and Risk of Esophageal and Gastric Cancer: A Meta-Analysis of Epidemiological Studies. Nutrients 2016, 8, 91. [CrossRef]

111. Romagnolo, D.F.; Selmin, O.I. Flavonoids and Cancer Prevention: A Review of the Evidence. J. Nutr. Gerontol. Geriatr. 2012, 31, 206-238. [CrossRef]

112. Martinez-Perez, C.; Ward, C.; Cook, G.; Mullen, P.; McPhail, D.; Harrison, D.J.; Langdon, S.P. Novel Flavonoids as Anti-Cancer Agents: Mechanisms of Action and Promise for Their Potential Application in Breast Cancer. Biochem. Soc. Trans. 2014, 42, 1017-1023. [CrossRef]

113. Hooper, L.; Kay, C.; Abdelhamid, A.; Kroon, P.A.; Cohn, J.S.; Rimm, E.B.; Cassidy, A. Effects of Chocolate, Cocoa, and Flavan-3-Ols on Cardiovascular Health: A Systematic Review and Meta-Analysis of Randomized Trials. Am. J. Clin. Nutr. 2012, 95, 740-751. [CrossRef] [PubMed]

114. Wang, X.; Ouyang, Y.Y.; Liu, J.; Zhao, G. Flavonoid Intake and Risk of CVD: A Systematic Review and Meta-Analysis of Prospective Cohort Studies. Br. J. Nutr. 2014, 111, 1-11. [CrossRef] [PubMed]

115. Rees, A.; Dodd, G.F.; Spencer, J.P.E. The Effects of Flavonoids on Cardiovascular Health: A Review of Human Intervention Trials and Implications for Cerebrovascular Function. Nutrients 2018, 10, 1852. [CrossRef] [PubMed]

116. Cheng, J.; Zhou, L.; Liu, Q.; Tickner, J.; Tan, Z.; Li, X.; Liu, M.; Lin, X.; Wang, T.; Pavlos, N.J.; et al. Cyanidin Chloride Inhibits Ovariectomy-Induced Osteoporosis by Suppressing RANKL-Mediated Osteoclastogenesis and Associated Signaling Pathways. J. Cell. Physiol. 2018, 233, 2502-2512. [CrossRef]

117. Beking, K.; Vieira, A. Flavonoid Intake and Disability-Adjusted Life Years Due to Alzheimer's and Related Dementias: A Population-Based Study Involving Twenty-Three Developed Countries. Public Health Nutr. 2010, 13, 1403-1409. [CrossRef]

118. Ninfali, P.; Antonini, E.; Frati, A.; Scarpa, E.-S. C-Glycosyl Flavonoids from Beta Vulgaris Cicla and Betalains from Beta Vulgaris Rubra: Antioxidant, Anticancer and Antiinflammatory Activities-A Review. Phytother. Res. 2017, 31, 871-884. [CrossRef]

119. Farzaei, M.H.; Singh, A.K.; Kumar, R.; Croley, C.R.; Pandey, A.K.; Coy-Barrera, E.; Patra, J.K.; Das, G.; Kerry, R.G.; Annunziata, G.; et al. Targeting Inflammation by Flavonoids: Novel Therapeutic Strategy for Metabolic Disorders. Int. J. Mol. Sci. 2019, $20,4957$. [CrossRef] [PubMed]

120. Farhat, G.; Drummond, S.; Al-Dujaili, E.A.S. Polyphenols and Their Role in Obesity Management: A Systematic Review of Randomized Clinical Trials. Phytother. Res. 2017, 31, 1005-1018. [CrossRef] [PubMed]

121. Al-Dosary, D.I.; Alhomida, A.S.; Ola, M.S. Protective Effects of Dietary Flavonoids in Diabetic Induced Retinal Neurodegeneration. Curr. Drug Targets 2017, 18, 1468-1476. [CrossRef]

122. Belwal, T.; Nabavi, S.F.; Nabavi, S.M.; Habtemariam, S. Dietary Anthocyanins and Insulin Resistance: When Food Becomes a Medicine. Nutrients 2017, 9, 1111. [CrossRef]

123. Chirumbolo, S.; Bjørklund, G.; Lysiuk, R.; Vella, A.; Lenchyk, L.; Upyr, T. Targeting Cancer with Phytochemicals via Their Fine Tuning of the Cell Survival Signaling Pathways. Int. J. Mol. Sci. 2018, 19, 3568. [CrossRef]

124. Dong, J.; Zhang, Q.; Cui, Q.; Huang, G.; Pan, X.; Li, S. Flavonoids and Naphthoflavonoids: Wider Roles in the Modulation of Cytochrome P450 Family 1 Enzymes. ChemMedChem 2016, 2102-2118. [CrossRef]

125. van der Heiden, E.; Bechoux, N.; Muller, M.; Sergent, T.; Schneider, Y.J.; Larondelle, Y.; Maghuin-Rogister, G.; Scippo, M.L. Food Flavonoid Aryl Hydrocarbon Receptor-Mediated Agonistic/Antagonistic/Synergic Activities in Human and Rat Reporter Gene Assays. Anal. Chim. Acta 2009, 637, 337-345. [CrossRef] [PubMed]

126. Doan, T.Q.; Connolly, L.; Igout, A.; Muller, M.; Scippo, M.L. In Vitro Differential Responses of Rat and Human Aryl Hydrocarbon Receptor to Two Distinct Ligands and to Different Polyphenols. Environ. Pollut. 2020, 265, 114966. [CrossRef]

127. Zhang, S.; Qin, C.; Safe, S.H. Flavonoids as Aryl Hydrocarbon Receptor Agonists/Antagonists: Effects of Structure and Cell Context. Environ. Health Perspect. 2003, 111, 1877-1882. [CrossRef] 
128. Ashida, H.; Fukuda, I.; Yamashita, T.; Kanazawa, K. Flavones and Flavonols at Dietary Levels Inhibit a Transformation of Aryl Hydrocarbon Receptor Induced by Dioxin. FEBS Lett. 2000, 476, 213-217. [CrossRef]

129. Ashida, H. Suppressive Effects of Flavonoids on Dioxin Toxicity. BioFactors 2000, 12, 201-206. [CrossRef]

130. Xue, Y.; Shui, X.; Su, W.; He, Y.; Lu, X.; Zhang, Y.; Yan, G.; Huang, S.; Lei, W.; Chen, C. Baicalin Inhibits Inflammation and Attenuates Myocardial Ischaemic Injury by Aryl Hydrocarbon Receptor. J. Pharm. Pharmacol. 2015, 67, 1756-1764. [CrossRef] [PubMed]

131. Zhu, W.; Chen, X.; Yu, J.; Xiao, Y.; Li, Y.; Wan, S.; Su, W.; Liang, D. Baicalin Modulates the Treg/Teff Balance to Alleviate Uveitis by Activating the Aryl Hydrocarbon Receptor. Biochem. Pharmacol. 2018, 154, 18-27. [CrossRef]

132. Arivazhagan, L.; Subramanian, S.P. Tangeretin, a Citrus Flavonoid Attenuates Oxidative Stress and Protects Hepatocellular Architecture in Rats with 7, 12 Dimethylbenz(a)Anthracene Induced Experimental Mammary Carcinoma. J. Funct. Foods 2015, 15, 339-353. [CrossRef]

133. Ronnekleiv-Kelly, S.M.; Nukaya, M.; Díaz-Díaz, C.J.; Megna, B.W.; Carney, P.R.; Geiger, P.G.; Kennedy, G.D. Aryl Hydrocarbon Receptor-Dependent Apoptotic Cell Death Induced by the Flavonoid Chrysin in Human Colorectal Cancer Cells. Cancer Lett. 2016, 370, 91-99. [CrossRef]

134. Feng, J.; Zheng, T.; Hou, Z.; Lv, C.; Xue, A.; Han, T.; Han, B.; Sun, X.; Wei, Y. Luteolin, an Aryl Hydrocarbon Receptor Ligand, Suppresses Tumor Metastasis in Vitro and in Vivo. Oncol Rep 2020, 44, 2231-2240. [CrossRef]

135. Jin, U.H.; Park, H.; Li, X.; Davidson, L.A.; Allred, C.; Patil, B.; Jayaprakasha, G.; Orr, A.A.; Mao, L.; Chapkin, R.S.; et al. Structure-Dependent Modulation of Aryl Hydrocarbon Receptor-Mediated Activities by Flavonoids. Toxicol. Sci. 2018, 164, 205-217. [CrossRef]

136. Goya-Jorge, E.; Giner, R.M.; Sylla-Iyarreta Veitía, M.; Gozalbes, R.; Barigye, S.J. Predictive Modeling of Aryl Hydrocarbon Receptor (AhR) Agonism. Chemosphere 2020, 127068. [CrossRef]

137. Park, H.; Jin, U.H.; Orr, A.A.; Echegaray, S.P.; Davidson, L.A.; Allred, C.D.; Chapkin, R.S.; Jayaraman, A.; Lee, K.; Tamamis, P.; et al. Isoflavones as Ah Receptor Agonists in Colon-Derived Cell Lines: Structure-Activity Relationships. Chem. Res. Toxicol. 2019, 32, 2353-2364. [CrossRef] [PubMed]

138. Sun, F.; Indran, I.R.; Zhang, Z.W.; Tan, M.H.E.; Li, Y.; Lim, Z.L.R.; Hua, R.; Yang, C.; Soon, F.F.; Li, J.; et al. A Novel Prostate Cancer Therapeutic Strategy Using Icaritin-Activated Arylhydrocarbon-Receptor to Co-Target Androgen Receptor and Its Splice Variants. Carcinogenesis 2015, 36, 757-768. [CrossRef] [PubMed]

139. Kaur, M.; Badhan, R.K.S. Phytochemical Mediated-Modulation of the Expression and Transporter Function of Breast Cancer Resistance Protein at the Blood-Brain Barrier: An in-Vitro Study. Brain Res. 2017, 1654, 9-23. [CrossRef] [PubMed]

140. Bostikova, Z.; Moserova, M.; Pavek, P.; Stiborova, M.; Hodek, P. Role of Dihydromyricetin in Cytochrome P450-Mediated Metabolism and Carcinogen Activation. Neuroendocrinol. Lett. 2015, 36, 46-52. [PubMed]

141. Wang, S.; Dunlap, T.L.; Howell, C.E.; Mbachu, O.C.; Rue, E.A.; Phansalkar, R.; Chen, S.N.; Pauli, G.F.; Dietz, B.M.; Bolton, J.L. Hop (Humulus Lupulus L.) Extract and 6-Prenylnaringenin Induce P450 1A1 Catalyzed Estrogen 2-Hydroxylation. Chem. Res. Toxicol. 2016, 29, 1142-1150. [CrossRef] [PubMed]

142. Tan, Y.Q.; Chiu-Leung, L.C.; Mei Lin, S.; Leung, L.K. The Citrus Flavonone Hesperetin Attenuates the Nuclear Translocation of Aryl Hydrocarbon Receptor. Comp. Biochem. Physiol. Part C Toxicol. Pharmacol. 2018, 210, 57-64. [CrossRef] [PubMed]

143. Wang, K.; Lv, Q.; Meng Miao, Y.; Miao Qiao, S.; Dai, Y.; Feng Wei, Z. Cardamonin, a Natural Flavone, Alleviates Inflammatory Bowel Disease by the Inhibition of NLRP3 Inflammasome Activation via an AhR/Nrf2/NQO1 Pathway. Biochem. Pharmacol. 2018, 155, 494-509. [CrossRef] [PubMed]

144. Dunlap, T.L.; Howell, C.E.; Mukand, N.; Chen, S.N.; Pauli, G.F.; Dietz, B.M.; Bolton, J.L. Red Clover Aryl Hydrocarbon Receptor (AhR) and Estrogen Receptor (ER) Agonists Enhance Genotoxic Estrogen Metabolism. Chem. Res. Toxicol. 2017, 30, $2084-2092$. [CrossRef] [PubMed]

145. Bialesova, L.; Novotna, A.; Macejova, D.; Brtko, J.; Dvorak, Z. Agonistic Effect of Selected Isoflavones on Arylhydrocarbon Receptor in a Novel AZ-AhR Transgenic Gene Reporter Human Cell Line. Gen. Physiol. Biophys. 2015, 34, 331-334. [CrossRef] [PubMed]

146. Froyen, E.B.; Steinberg, F.M. Genistein Decreases Basal Hepatic Cytochrome P450 1A1 Protein Expression and Activity in Swiss Webster Mice. Nutr. Res. 2016, 36, 430-439. [CrossRef] [PubMed]

147. Ashida, H.; Harada, K.; Mishima, S.; Mitani, T.; Yamashita, Y.; Matsumura, F. Luteolin Suppresses TCDD-Induced Wasting Syndrome in a Cultured Adipocyte Model. Pestic. Biochem. Physiol. 2015, 120, 14-20. [CrossRef] [PubMed]

148. Miao, Y.; Lv, Q.; Qiao, S.; Yang, L.; Tao, Y.; Yan, W.; Wang, P.; Cao, N.; Dai, Y.; Wei, Z. Alpinetin Improves Intestinal Barrier Homeostasis via Regulating AhR/Suv39h1/TSC2/MTORC1/Autophagy Pathway. Toxicol. Appl. Pharmacol. 2019, $384,1-15$. [CrossRef]

149. Lv, Q.; Shi, C.; Qiao, S.; Cao, N.; Guan, C.; Dai, Y.; Wei, Z. Alpinetin Exerts Anti-Colitis Efficacy by Activating AhR, Regulating MiR-302/DNMT- 1/CREB Signals, and Therefore Promoting Treg Differentiation. Cell Death Dis. 2018, 9, 1-25. [CrossRef]

150. Fukuda, I.; Mukai, R.; Kawase, M.; Yoshida, K.; Ashida, H. Interaction between the Aryl Hydrocarbon Receptor and Its Antagonists, Flavonoids. Biochem. Biophys. Res. Commun. 2007, 359, 822-827. [CrossRef]

151. Medjakovic, S.; Jungbauer, A. Red Clover Isoflavones Biochanin A and Formononetin Are Potent Ligands of the Human Aryl Hydrocarbon Receptor. J. Steroid Biochem. Mol. Biol. 2008, 108, 171-177. [CrossRef] 